\title{
The influence of boreal biomass burning emissions on the distribution of tropospheric ozone over North America and the North Atlantic during 2010
}

\author{
M. Parrington ${ }^{1}$, P. I. Palmer ${ }^{1}$, D. K. Henze ${ }^{2}$, D. W. Tarasick ${ }^{3}$, E. J. Hyer ${ }^{4}$, R. C. Owen ${ }^{5}$, D. Helmig ${ }^{6}$, C. Clerbaux ${ }^{7}$, \\ K. W. Bowman ${ }^{8}$, M. N. Deeter ${ }^{9}$, E. M. Barratt ${ }^{1}$, P.-F. Coheur ${ }^{10}$, D. Hurtmans ${ }^{10}$, Z. Jiang ${ }^{11}$, M. George ${ }^{7}$, and \\ J. R. Worden ${ }^{8}$ \\ ${ }^{1}$ School of GeoSciences, The University of Edinburgh, Edinburgh, UK \\ ${ }^{2}$ Department of Mechanical Engineering, University of Colorado, Boulder, Colorado, USA \\ ${ }^{3}$ Air Quality Research Division, Environment Canada, Downsview, Ontario, Canada \\ ${ }^{4}$ Marine Meteorology Division, Naval Research Laboratory, Monterey, California, USA \\ ${ }^{5}$ Department of Civil and Environmental Engineering, Michigan Technological University, Houghton, Michigan, USA \\ ${ }^{6}$ Institute of Arctic and Alpine Research, University of Colorado, Boulder, Colorado, USA \\ ${ }^{7}$ UPMC Univ. Paris 06; Université Versailles St.-Quentin; CNRS/INSU, LATMOS-IPSL, Paris, France \\ ${ }^{8}$ Jet Propulsion Laboratory, California Institute of Technology, Pasadena, California, USA \\ ${ }^{9}$ Atmospheric Chemistry Division, National Center for Atmospheric Research, Boulder, Colorado, USA \\ ${ }^{10}$ Spectroscopie de l'Atmosphère, Service de Chimie Quantique et Photophysique, Université Libre de Bruxelles (ULB), \\ Brussels, Belgium \\ ${ }^{11}$ Department of Physics, University of Toronto, Toronto, Ontario, Canada \\ Correspondence to: M. Parrington (mark.parrington@ed.ac.uk)
}

Received: 1 September 2011 - Published in Atmos. Chem. Phys. Discuss.: 8 September 2011

Revised: 13 February 2012 - Accepted: 15 February 2012 - Published: 21 February 2012

\begin{abstract}
We have analysed the sensitivity of the tropospheric ozone distribution over North America and the North Atlantic to boreal biomass burning emissions during the summer of 2010 using the GEOS-Chem 3-D global tropospheric chemical transport model and observations from in situ and satellite instruments. We show that the model ozone distribution is consistent with observations from the Pico Mountain Observatory in the Azores, ozonesondes across Canada, and the Tropospheric Emission Spectrometer (TES) and Infrared Atmospheric Sounding Instrument (IASI) satellite instruments. Mean biases between the model and observed ozone mixing ratio in the free troposphere were less than $10 \mathrm{ppbv}$. We used the adjoint of GEOS-Chem to show the model ozone distribution in the free troposphere over Maritime Canada is largely sensitive to $\mathrm{NO}_{\mathrm{x}}$ emissions from biomass burning sources in Central Canada, lightning sources in the central US, and anthropogenic sources in the eastern US and southeastern Canada. We also used the adjoint of GEOS-Chem to evaluate the Fire Locating And Monitoring of Burning Emis-
\end{abstract}

sions (FLAMBE) inventory through assimilation of $\mathrm{CO}$ observations from the Measurements Of Pollution In The Troposphere (MOPITT) satellite instrument. The CO inversion showed that, on average, the FLAMBE emissions needed to be reduced to $89 \%$ of their original values, with scaling factors ranging from $12 \%$ to $102 \%$, to fit the MOPITT observations in the boreal regions. Applying the $\mathrm{CO}$ scaling factors to all species emitted from boreal biomass burning sources led to a decrease of the model tropospheric distributions of $\mathrm{CO}, \mathrm{PAN}$, and $\mathrm{NO}_{\mathrm{x}}$ by as much as $-20 \mathrm{ppbv},-50 \mathrm{pptv}$, and -20 pptv respectively. The modification of the biomass burning emission estimates reduced the model ozone distribution by approximately $-3 \mathrm{ppbv}(-8 \%)$ and on average improved the agreement of the model ozone distribution compared to the observations throughout the free troposphere, reducing the mean model bias from 5.5 to $4.0 \mathrm{ppbv}$ for the Pico Mountain Observatory, 3.0 to $0.9 \mathrm{ppbv}$ for ozonesondes, 2.0 to $0.9 \mathrm{ppbv}$ for TES, and 2.8 to $1.4 \mathrm{ppbv}$ for IASI. 


\section{Introduction}

Tropospheric ozone is an important atmospheric constituent in the contexts of climate, air quality, and tropospheric chemistry. The main sources of tropospheric ozone are the oxidation of carbon monoxide (CO) and volatile organic compounds (VOCs) in the presence of nitrogen oxides $\left(\mathrm{NO}_{\mathrm{x}}\right)$ and transport from the stratosphere. Removal of ozone from the troposphere is through dry deposition and photochemical destruction. Tropospheric ozone has a photochemical lifetime ranging from a few days in the planetary boundary layer (PBL) to several days and weeks in the free troposphere, where it can be subject to intercontinental transport and affect tropospheric composition far from the source region. The ozone distribution over the North Atlantic is of particular interest in this respect as it is strongly influenced by the transport of precursor emissions, both natural and anthropogenic in origin, from the North American continental PBL and subsequent chemical processes in the outflow (e.g. Fehsenfeld et al., 2006). Quantifying the influence of the different parameters that affect the North Atlantic tropospheric ozone distribution is important as this outflow and its subsequent chemical transformation can have an impact on tropospheric composition and air quality further downwind, e.g. over Europe (Derwent et al., 2004). In this paper we evaluate the tropospheric ozone distribution over North America and the North Atlantic during the summer of 2010 and its sensitivity to ozone precursor emissions, particularly from boreal biomass burning sources, using the GEOS-Chem numerical model of atmospheric chemistry and transport and in situ and satellite observations.

A number of previous studies have focussed on the distribution of tropospheric ozone, and the influence of North American pollution, over the North Atlantic. The first longterm measurements of surface level ozone across the Atlantic Ocean were made from ship-based measurements in the 1970s and 1980s (Winkler, 1988). The North Atlantic Regional Experiment (NARE) (Fehsenfeld et al., 1996) was an airborne and ground-based measurement campaign conducted in the spring and summer of 1993 to measure the distribution of tropospheric ozone and its precursors over the region. The first intensive measurements of the tropospheric ozone distribution over the North Atlantic were made during NARE with daily ozonesondes launched from Iceland, Newfoundland, Bermuda, and the Azores (Oltmans et al., 1996). In 2004, the International Consortium for Atmospheric Research on Transport and Transformation (ICARTT) (Fehsenfeld et al., 2006) sampled North American pollution outflow as it was transported across the North Atlantic with airborne measurements made from the Azores (Lewis et al., 2007) and Europe (Real et al., 2007). In situ measurements of ozone and its precursors have also been made in the lower Atlantic free troposphere from the Pico Mountain Observatory on the peak of Mt. Pico in the Azores at $38.47^{\circ} \mathrm{N}, 28.40^{\circ} \mathrm{W}, 2225 \mathrm{~m}$ altitude (Honrath et al., 2004; Helmig et al., 2008). Model studies of the outflow of North American ozone precursor emissions and their impact on the tropospheric ozone distribution over the North Atlantic have been performed. Flatoy et al. (1996) and Kasibhatla et al. (1996) presented 3-D model analyses of the summertime tropospheric ozone distribution over the North Atlantic during the NARE campaign period. More recent analysis used the GEOS-Chem chemistry transport model to evaluate the transport of North American pollution outflow across the Atlantic and its subsequent impact on surface ozone over Europe (Li et al., 2002).

The main focus of these previous studies has been on the transport of ozone precursor emissions, from anthropogenic sources, out from the North American PBL and over the Atlantic. Measurements made during ICARTT did, however, sample plumes of Canadian biomass burning outflow along the eastern seaboard and over the North Atlantic. These measurements showed an unusual mixture of organic compounds within $\mathrm{NO}_{\mathrm{y}}$ $\left(\mathrm{NO}+\mathrm{NO}_{2}+\mathrm{PANs}+\mathrm{HNO}_{3}+\mathrm{HONO}+\mathrm{NO}_{3}+2 \mathrm{~N}_{2} \mathrm{O}_{5}+\right.$ organic nitrates) that existed only within biomass burning plumes over the Atlantic (Lewis et al., 2007). Much of this $\mathrm{NO}_{\mathrm{y}}$ was held as peroxyacetyl nitrate (PAN) but with an abundance higher than expected and that was highly sensitive to slight changes in altitude and temperature. Measurements of ozone, $\mathrm{CO}, \mathrm{NO}_{\mathrm{x}}$, and $\mathrm{NO}_{\mathrm{y}}$ have been made at the Pico Mountain Observatory in the mid-Atlantic (Lapina et al., 2006; Val Martin et al., 2006; Helmig et al., 2008). Years with high boreal fire activity have been shown to increase ozone mixing ratios in the free troposphere over this site by up to $10 \mathrm{ppbv}$ (Lapina et al., 2006) with photochemically aged biomass burning plumes influencing tropospheric oxidant chemistry after 1-2 weeks of transport to the region (Helmig et al., 2008). In situ measurements of biomass burning outflow close to boreal source regions in North America were made during the Arctic Research of the Composition of the Troposphere from Aircraft and Satellites (ARCTAS) campaign in the summer of 2008. Analysis of the fresh plumes observed during ARCTAS showed little evidence of ozone formation in the aircraft, satellite, and model results (Alvarado et al., 2010). Correlations between ozone and $\mathrm{CO}$ were observed in some of the plumes ( 9 out of 34) with an average ozone enhancement of $+0.5 \% \pm 1.9 \%$ consistent with a previous analysis of biomass burning outflow over Canada (Mauzerall et al., 1996). Observations of biomass burning plumes by the TES satellite instrument during ARCTAS (Alvarado et al., 2010) and over Siberia in the summer of 2006 (Verma et al., 2009) showed some evidence of ozone production in the smoke plume but also showed ozone depletion and were unable to attribute ozone changes to the fire emissions.

The quantifying the impact of BOReal forest fires on Tropospheric oxidants over the Atlantic using Aircraft and Satellites (BORTAS) project is the most recent study of the tropospheric composition over the North Atlantic, combining model outputs with in situ and satellite observations of key 
tracers of boreal biomass burning and tropospheric oxidant chemistry. The initial phase of the BORTAS study took place in the summer of 2010, consisting of ground-based and ozonesonde measurements of biomass burning outflow, and is described in the following section. The second phase of the BORTAS study took place in the summer of 2011 and built on the first phase with an aircraft measurement campaign including instrumentation to fully evaluate the speciation of $\mathrm{NO}_{\mathrm{y}}$ and the chemistry within plumes of boreal biomass burning outflow as they are transported over the North Atlantic.

This paper evaluates the tropospheric ozone distribution over North America and the North Atlantic Ocean in the summer of 2010 using the GEOS-Chem chemical transport model (CTM) in conjunction with in situ and satellite observations. The paper also investigates the influence of boreal biomass burning emissions on the tropospheric ozone distribution using satellite observations to constrain the biomass burning source estimates. The paper is arranged as follows: An overview of the BORTAS project and boreal biomass burning activity over the period of the first phase of the project in the summer of 2010 is presented in Sect. 2; Sect. 3 presents an overview of the GEOS-Chem model of chemistry and transport used in this analysis; Sect. 4 presents the mean 3-D tropospheric ozone distribution for the first phase of the BORTAS campaign with output from the GEOS-Chem CTM evaluated against measurements made by ozonesondes launched from sites across Canada and by in situ observations made at the Pico Mountain Observatory, and satellite observations made by the Tropospheric Emission Spectrometer (TES) and Infrared Atmospheric Sounding Instrument (IASI); evaluation of the sensitivity of the model tropospheric ozone distribution to the model inputs, with a particular focus on boreal biomass burning emission estimates, which we constrain through an inversion of $\mathrm{CO}$ observations from the Measurements Of Pollution In The Troposphere (MOPITT) satellite instrument, is presented in Sect. 5; we conclude in Sect. 6.

\section{The BORTAS-A measurement campaign}

The analysis of the summer 2010 tropospheric ozone distribution, presented here, is part of a multi-national project, led by the University of Edinburgh, aimed at Quantifying the impact of BOReal forest fires on Tropospheric oxidants over the Atlantic using Aircraft and Satellites (the BORTAS project, http://www.geos.ed.ac.uk/research/eochem/bortas/). The overarching scientific aims of the BORTAS project are to: (1) sample biomass burning outflow from boreal North America over the western boundary of the North Atlantic using ground-based, balloon, and aircraft measurements; (2) describe the observed chemistry within plumes using numerical models of atmospheric chemistry and transport, paying particular attention to the $\mathrm{NO}_{\mathrm{y}}$ and organic chemistry; (3) quantify the impact of boreal forest fires on oxidant chemistry over the temperate and subtropical Atlantic Ocean; and (4) detect, validate and quantify the impact of boreal biomass burning on global tropospheric composition using data from space-borne sensors. Central to BORTAS is a measurement campaign with the UK Facility for Airborne Atmospheric Measurements (FAAM) BAe146 research aircraft, based out of Halifax, Nova Scotia, Canada, supported by a variety of ground-based measurements at Dalhousie University in Halifax and ozonesondes launched by Environment Canada from a number of sites across eastern Canada. The aircraft measurement campaign was originally scheduled to take place in July/August 2010 but was postponed until July/August 2011, due to disruption of air traffic over the Atlantic Ocean by the eruption of the Eyjafjallajökull volcano in Iceland during spring 2010. Although the aircraft measurement campaign was postponed, the support measurements went ahead as planned through July/August 2010 and make up phase A of the project, referred to as BORTAS-A from here on in. The support measurements of relevance to the work presented in this paper is a network of seven measurement sites across central and eastern Canada from which daily ozonesondes were launched between 12 July and 4 August inclusive, the original dates of the BORTAS-A aircraft campaign. The location of the ozonesonde launch sites, along with the time of the daily launches and the number of sondes launched from each site, are listed in Table 1 and shown in Fig. 2a. The satellite data central to analysis of the BORTASA campaign period are ozone observations from the Infrared Atmospheric Sounding Instrument (IASI) and Tropospheric Emission Spectrometer (TES), and CO observations from the Measurements Of Pollution In The Troposphere (MOPITT) instrument.

Additional support measurements made at Dalhousie University included the Dalhousie University Raman Lidar (Duck et al., 2007), which provided continuous, under clear sky conditions, measurements of tropospheric aerosol profiles throughout the campaign period along with groundbased measurements of particulate matter and its speciation, wind profiling, surface ozone and total column of a number of atmospheric tracers. Further satellite observations for BORTAS data analysis were retrieved profiles of ozone, $\mathrm{CO}$, and organic species associated with biomass burning outflow from the Atmospheric Chemistry Experiment Fourier Transform Spectrometer (ACE-FTS) but are beyond the scope of this work and have been analysed in other papers (e.g. Tereszchuk et al., 2011).

\subsection{Boreal biomass burning activity during BORTAS-A}

Boreal biomass burning activity during the BORTAS-A campaign is described by the Fire Locating And Monitoring of Burning Emissions (FLAMBE) inventory (Reid et al., 2009) to estimate the total carbon emissions from boreal biomass burning sources during the summer of 2010. The FLAMBE 
Table 1. Location of ozonesonde launch sites during the BORTAS-A measurement campaign, the typical sonde launch time at each site in hours UTC, and the number of ozonesondes launched from each site between 12 July and 4 August 2010. The right-hand column reports the mean and median of the model minus ozonesonde bias in the troposphere (from the surface to $10 \mathrm{~km}$ ). The distribution of the launch sites across Canada is shown in Fig. 2a.

\begin{tabular}{|c|c|c|c|c|c|}
\hline Launch site & $\begin{array}{l}\text { Longitude } \\
{ }^{\circ} \mathrm{W}\end{array}$ & $\begin{array}{l}\text { Latitude } \\
{ }^{\circ} \mathrm{N}\end{array}$ & $\begin{array}{l}\text { Launch time } \\
\text { UTC }\end{array}$ & Number & $\begin{array}{l}\text { Mean (median) model bias } \\
\text { ppbv }\end{array}$ \\
\hline Bratt's Lake, SK & 104.7 & 50.2 & 14 & 22 & $1.1(4.1)$ \\
\hline Egbert, ON & 79.8 & 44.2 & 17 & 21 & $7.8(9.4)$ \\
\hline Walsingham, ON & 80.6 & 42.6 & 17 & 17 & $13.0(11.9)$ \\
\hline Montreal, QC & 73.4 & 45.5 & 17 & 26 & $0.6(2.8)$ \\
\hline Goose Bay, NL & 60.1 & 53.5 & 11 & 22 & $-0.9(0.2)$ \\
\hline Sable Island, NS & 60.0 & 44.0 & 23 & 22 & $4.1(5.0)$ \\
\hline Yarmouth, NS & 66.1 & 43.9 & 23 & 23 & $2.8(4.8)$ \\
\hline
\end{tabular}

inventory provides hourly estimates of carbon and aerosol emissions based on fire data from geostationary and polar orbiting satellite platforms. Active fire data from the Geostationary Operational Environmental Satellite (GOES) platforms, and the two Moderate Resolution Imaging Spectroradiometer (MODIS) instruments on the NASA EOS Aqua and Terra platforms, are combined with a $1 \mathrm{~km} \times 1 \mathrm{~km}$ land use database. MODIS active fire data are extrapolated from the roughly 4-times daily observations using a diurnal cycle that releases $90 \%$ of the total emissions between 09:00 and 19:00 local time (Reid et al., 2004). The FLAMBE inventory was also used in the analysis presented here to provide global biomass burning emission estimates for the GEOSChem CTM described in the next section.

Figure 1 shows the daily distribution of GOES and MODIS active fire data used by the FLAMBE inventory and the estimated total carbon emissions, in $\mathrm{kg}$, between 1 July and 4 August 2010. Figure 1a shows the daily distribution of fire hotspots, sampled on a horizontal grid with a resolution of $0.5^{\circ}$ latitude $\times 0.67^{\circ}$ longitude, across the northern extra-tropics. Only the biomass burning emissions for the boreal region (defined as all latitudes poleward of $50^{\circ} \mathrm{N}$, blue box in Fig. 1a) are evaluated here. Subregions of the boreal region are defined for boreal North America $\left(170^{\circ}-50^{\circ} \mathrm{W}\right.$, $\left.50^{\circ}-75^{\circ} \mathrm{N}\right)$, Central Canada $\left(120^{\circ}-90^{\circ} \mathrm{W}, 52^{\circ}-62^{\circ} \mathrm{N}\right)$, and Eastern Siberia $\left(110^{\circ}-180^{\circ} \mathrm{E}, 50^{\circ}-75^{\circ} \mathrm{N}\right)$ denoted by gold, red and green boxes in Fig. 1a respectively. Fires in Alaska, southern Central Canada, and eastern Canada were more prominent in the first half of the campaign period, with later fires in British Columbia and northern Saskatchewan in Central Canada. Fires over Eastern Siberia burned throughout the period with widespread activity continuing into the beginning of August.

Figure $1 b$ shows timeseries of the daily total carbon emissions over the defined time period for each region. Emissions over the whole boreal region increase steadily from values of approximately $10^{13} \mathrm{~kg}$ at the beginning of July to a peak value of almost $1.4 \times 10^{14} \mathrm{~kg}$ on day 211 (30 July).
The Eastern Siberia region is generally the largest contributor to the total boreal carbon emissions apart from a three day period between day numbers 192 and 195 (11 to 14 July) when the North American emissions are larger. The carbon emissions from boreal North America generally remain fairly constant at less than $10^{13} \mathrm{~kg}$ with peak values of $2 \times 10^{13} \mathrm{~kg}$ on days 194 (13 July) and 205 (24 July). The boreal North American carbon emissions are largely dominated by the Central Canada region until day 208 (27 July) when the North American emissions show an increase up to $2 \times 10^{13} \mathrm{~kg}$ while the Central Canada emissions remain fairly constant at approximately $5 \times 10^{12} \mathrm{~kg}$. The total carbon emitted from 1 July to 4 August 2010 is $1.2 \times 10^{15} \mathrm{~kg}$ for the boreal region, $2.7 \times 10^{14} \mathrm{~kg}$ for North America, $1.8 \times 10^{14} \mathrm{~kg}$ for Central Canada, and $6.8 \times 10^{14} \mathrm{~kg}$ for Eastern Siberia.

\section{The GEOS-Chem global 3-D chemistry transport model}

Analysis of the impact of boreal biomass burning on tropospheric chemistry over the BORTAS-A campaign period is performed with the GEOS-Chem CTM. The model provides an effective tool for evaluating the chemical state of the atmosphere and is used in the analysis to estimate the global tropospheric ozone distribution and integrate different observations available over the campaign period. GEOSChem is a global 3-D model driven by assimilated meteorological observations from the NASA Goddard Earth Observing System version 5 (GEOS-5) from the Global Modeling and Assimilation Office (GMAO). The meteorological fields have a horizontal resolution of $0.5^{\circ}$ latitude $\times 0.67^{\circ}$ longitude with 72 levels in the vertical, and a temporal resolution of $6 \mathrm{~h}$ ( $3 \mathrm{~h}$ for surface fields). In the work presented here we use v8-02-04 of GEOS-Chem with a horizontal resolution of $2^{\circ}$ latitude $\times 2.5^{\circ}$ longitude. Biomass burning emission estimates used in the model are from the FLAMBE inventory (Reid et al., 2009) described in the previous section. The FLAMBE carbon emissions are aggregated to the horizontal 


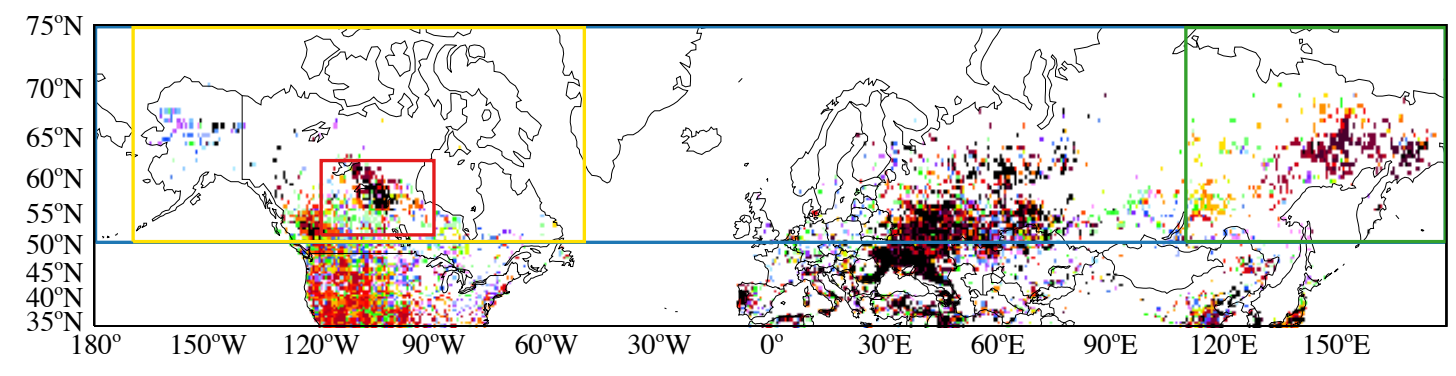

(a)
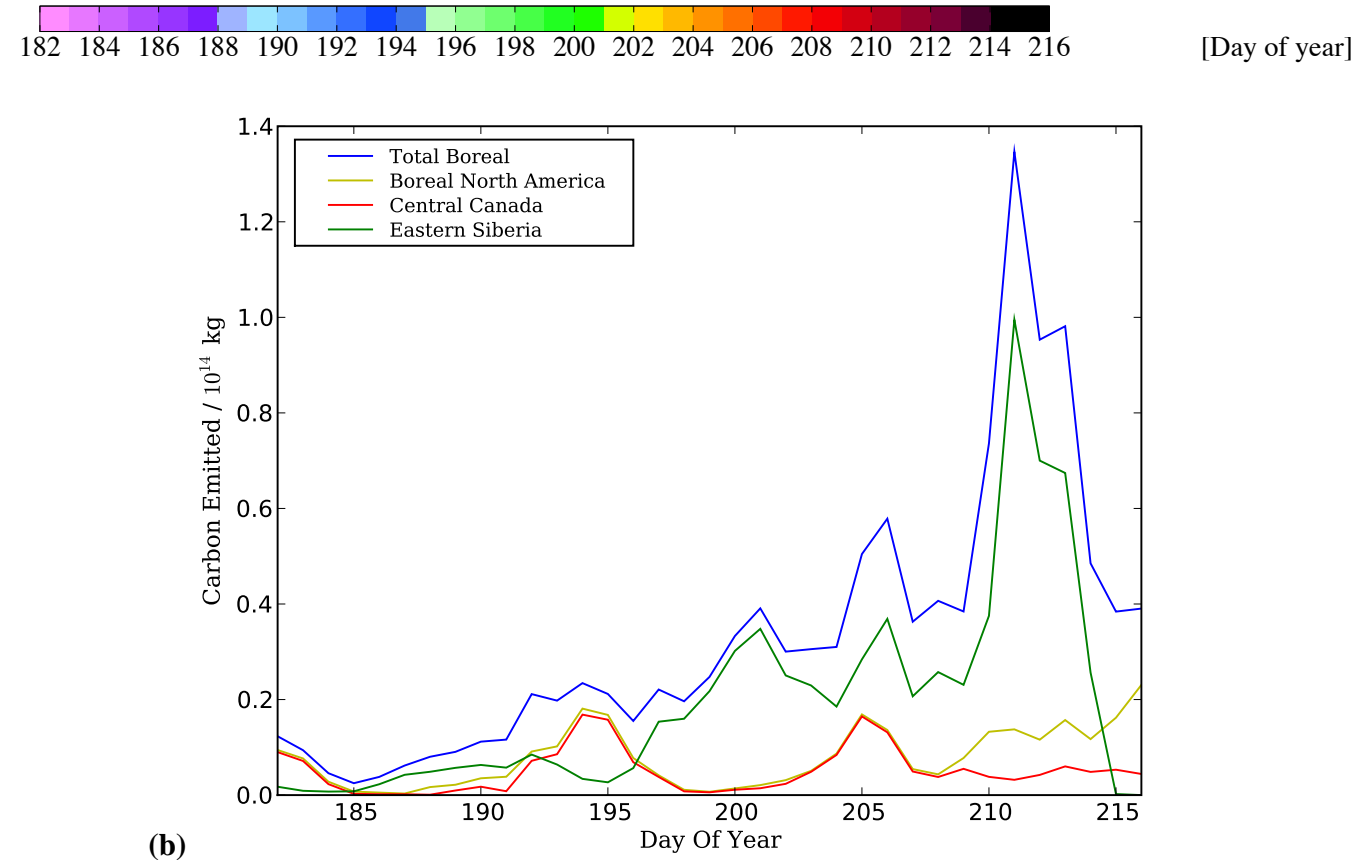

Fig. 1. Daily distribution of GOES and MODIS active fire used in the FLAMBE inventory and the estimated total carbon emissions, in kg, from 1 July (day 182) and 4 August (day 216) 2010. Plot (a) shows the distribution of fire hotspots across the northern extra-tropics as a function of day of year. Plot (b) shows timeseries of the daily total carbon emitted for the boreal region (latitudes $>50^{\circ} \mathrm{N}$ ), boreal North America $\left(170^{\circ}-50^{\circ} \mathrm{W}, 50^{\circ}-75^{\circ} \mathrm{N}\right)$, Central Canada $\left(120^{\circ}-90^{\circ} \mathrm{W}, 52^{\circ}-62^{\circ} \mathrm{N}\right)$, and Eastern Siberia $\left(110^{\circ}-180^{\circ} \mathrm{E}, 50^{\circ}-75^{\circ} \mathrm{N}\right)$. Line colours in plot (b) correspond to the boxes shown in plot (a) in which total emissions for each region are defined.

resolution of the model simulation and scaled for individual gas and aerosol phase biomass burning tracers using emission factors from Andreae and Merlet (2001). The gas phase species emitted by biomass burning in the model are $\mathrm{NO}_{\mathrm{x}}$, $\mathrm{CO}$, lumped $>=\mathrm{C} 4$ alkanes, acetone, methyl ethyl ketone, acetaldehyde, lumped $>=\mathrm{C} 3$ alkenes, propane, formaldehyde, and ethane. Aerosols emitted by biomass burning are $\mathrm{SO}_{2}, \mathrm{NH}_{3}$, organic carbon, and black carbon. The biomass burning emissions are distributed uniformly throughout the PBL using boundary layer heights from GEOS-5. Anthropogenic emission estimates in the model are provided for North America on a regional basis by the Environmental Protection Agency (EPA) National Emissions Inventory 1999 (NEI99) updated for the eastern United States (Hudman et al., 2007) for the US; the Big Bend Regional Aerosol and Visibility Observational (BRAVO) study for Mexico (Kuhns et al., 2005); and the National Pollutant Release Inventory
(NPRI) Criteria Air Contaminants (CAC) emission estimates for Canada. We use Asian anthropogenic emission estimates prepared for the NASA INTEX-B mission in 2006 (Zhang et al., 2009b), and European emission estimates are from the European Monitoring and Evaluation Programme (EMEP) inventory. Biogenic emissions of isoprene and other nonmethane VOCs are from the Model of Emissions of Gases and Aerosols from Nature (MEGAN) version 2.1 (Guenther et al., 2006). The lightning source of $\mathrm{NO}_{\mathrm{x}}$ in GEOS-Chem is estimated from lightning flash rates calculated using deep convective cloud top heights (Price and Rind, 1992) provided from GEOS-5, locally redistributed using a seasonally varying climatology of lightning flash counts observed from space by the Optical Transient Detector (OTD) and the Lightning Imaging Sensor (LIS) (Sauvage et al., 2007); the vertical distribution of the source is imposed according to Pickering et al. (1998). Emissions of $\mathrm{NO}_{\mathrm{x}}$ from soil sources 


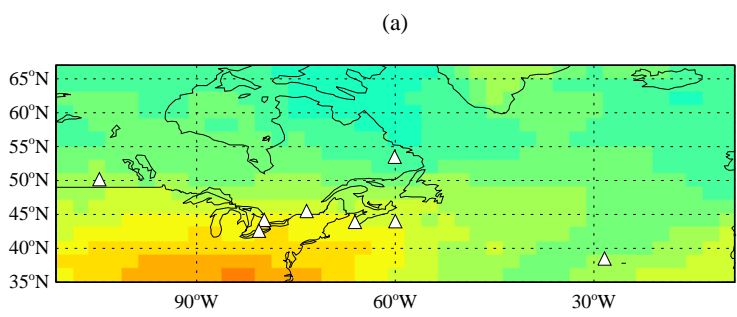

[ppbv]

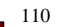

(b)

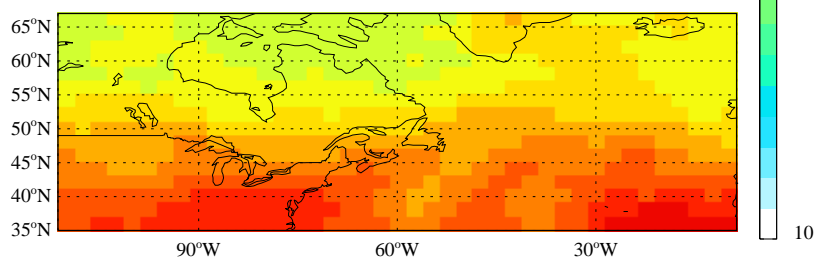

(c)

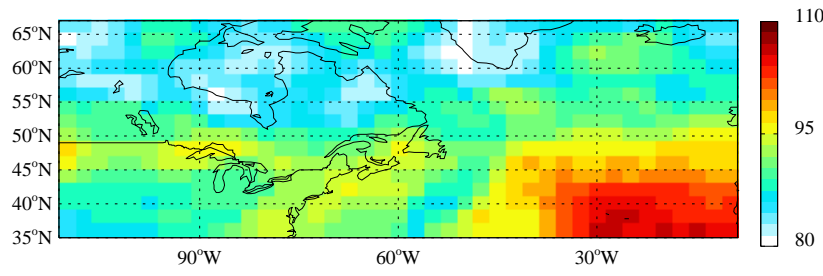

Fig. 2. Mean GEOS-Chem model ozone distribution (ppbv) across North America and the North Atlantic at (a) $750 \mathrm{hPa}(2.2 \mathrm{~km})$, (b) $500 \mathrm{hPa}(5.5 \mathrm{~km})$, and (c) $310 \mathrm{hPa}(8.9 \mathrm{~km})$ from 12 July to 4 August 2010. White triangles in plot (a) show the location of ozonesonde launch sites used during the BORTAS-A campaign across Canada, listed in Table 1, and the Pico Mountain Observatory in the midAtlantic.

are estimated using the scheme described by Wang et al. (1998). The stratospheric ozone distribution is described by a linearized ozone (Linoz) parameterization (McLinden et al., 2000). For the inversion of MOPITT data presented in Sect. 5.2 a CO only version of the model is used in which secondary chemical sources of $\mathrm{CO}$ through oxidation of methane and non methane volatile organic compounds are treated following Duncan et al. (2007) in which the subsequent production of $\mathrm{CO}$ is assumed to be instantaneous. This source of $\mathrm{CO}$ is modelled by increasing the primary CO emissions from combustion by $19 \%$ and $11 \%$ for emissions from fuel combustion and biomass burning, respectively (Duncan et al., 2007).

\section{Model and observed tropospheric ozone distribution over North America and the North Atlantic}

Figure 2 shows the mean model tropospheric ozone distribution at 750,500 , and $310 \mathrm{hPa}$ (corresponding to approximate altitudes of 2.2, 5.5, and $8.9 \mathrm{~km}$ respectively), across North America and the North Atlantic averaged over the BORTASA campaign period. The model ozone distribution at $750 \mathrm{hPa}$ shows an area of relatively high ozone mixing ratios (between 60 and $75 \mathrm{ppbv}$ ) localised predominantly over the eastern US and extending across the North American Basin to the $60^{\circ} \mathrm{W}$ meridian. Background model ozone mixing ratios across the rest of the domain at this level are in the range 40-60 ppbv (Fig. 2a). The mid-tropospheric, $500 \mathrm{hPa}$, ozone distribution similarly shows relatively high ozone values ( $>75 \mathrm{ppbv})$ across the eastern US and North American Basin along with plumes extending across the ocean equatorward of $50^{\circ} \mathrm{N}$, with peak values of approximately $80 \mathrm{ppbv}$ between $30^{\circ} \mathrm{W}$ and western Europe. Moderate model ozone values $(60-70 \mathrm{ppbv})$ are shown across Canada at this pressure level, with an apparent north-south gradient in ozone mixing ratio reflecting the relatively larger sources of ozone precursors across the US. We found using a model calculation that tagged ozone produced in the boreal (latitudes poleward of $50^{\circ} \mathrm{N}$ ) and non-boreal regions, not shown, that this gradient results from more numerous and stronger ozone precursor emissions in the non-boreal regions. At $310 \mathrm{hPa}$ the model ozone distribution is dominated by high mixing ratios (>95 ppbv) over the eastern Atlantic ocean and centred on the Azores. Across North America moderately elevated ozone mixing ratios (90-95 ppbv compared to background values of 80-90 ppbv) extend along the US-Canada border and along the east coast of the US and Canada up to $50^{\circ} \mathrm{N}$. Localised areas of ozone at these moderately elevated values are also seen at the higher latitudes to the west and east of Hudson Bay, and to the west of Iceland.

In the following sub-sections we evaluate the model ozone distribution against in situ measurements from ozonesondes and the Pico Mountain Observatory, and observations from the TES and IASI satellite instruments.

\subsection{GEOS-Chem vs. ozonesonde profiles}

Ozonesondes are balloon borne instruments that provide precise, vertically resolved, measurements of the atmospheric ozone mixing ratio during the balloon ascent through its electro-chemical reaction in an aqueous solution of potassium iodide. The inherent response time of the measurement is about 20-30 s and corresponds to a vertical resolution of $100-150 \mathrm{~m}$ for a balloon ascent of $4-5 \mathrm{~m} \mathrm{~s}^{-1}$. The accuracy of ozonesonde measurements in the troposphere is typically smaller than $10 \%$ (Thompson et al., 2011). A detailed overview of the observing capabilities of ozonesondes, and their role in measurement campaigns over recent years was recently presented by Thompson et al. (2011).

Throughout the BORTAS-A campaign daily launches of ozonesondes were performed from seven launch sites distributed across Canada between the sources of boreal biomass burning and the Maritime provinces. Figure 2a and Table 1 show the ozonesonde launch sites used during 

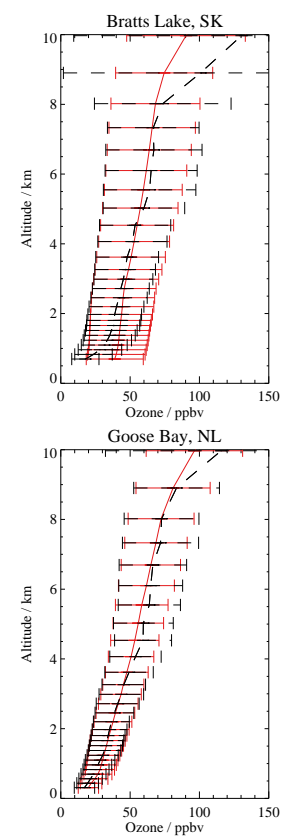
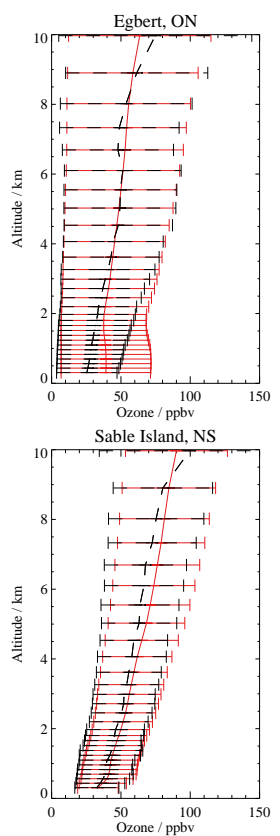
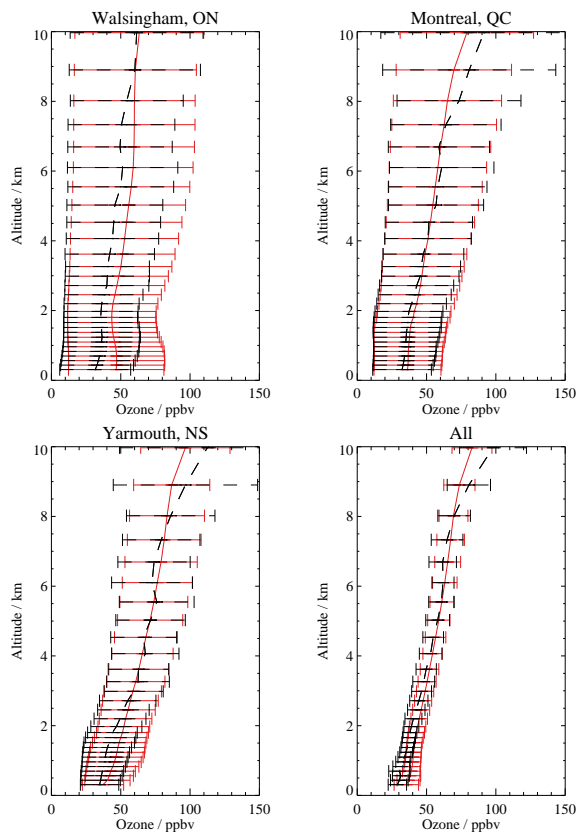

Fig. 3. Mean model and observed tropospheric ozone profiles over each of the ozonesonde launch sites listed in Table 1. Black dashed lines show the mean ozonesonde profile at each site and red solid lines show the mean spatially and temporally co-located GEOS-Chem ozone profile to each ozonesonde. Error bars show the $1-\sigma$ standard deviation. The bottom right plot is the mean ozone profile from all 153 ozonesondes launched throughout the campaign.

BORTAS-A with their location and the total number of ozonesondes launched from each site during the campaign. Figure 3 shows mean ozonesonde profiles, averaged over the GEOS-Chem vertical levels, and the co-located (in space and time) model ozone profiles for the individual launch sites. In general the mean bias between the ozonesonde and model ozone profiles is less than $10 \mathrm{ppbv}$ throughout the lower and free troposphere. In the upper troposphere (altitudes above $8 \mathrm{~km}$ ) the model generally shows a relatively large ( $>10 \mathrm{ppbv}$ ) negative bias compared to all ozonesonde locations except Walsingham. The largest mean model biases in the lower troposphere tend to occur below $2 \mathrm{~km}$ and are generally positive, in some cases in excess of $10 \mathrm{ppbv}$, and are most prominent at Bratt's Lake, Egbert, Walsingham, and Yarmouth. In the free troposphere at all sites, the mean bias is within \pm 5 ppbv. At each launch site, both positive (notably at Walsingham and Sable Island) and negative (Goose Bay) biases are shown in the free troposphere but differences in the under- or over-estimates of the model ozone distribution do not show any apparent geographical dependence. The comparison for Bratt's Lake is unusual in that it shows both positive (below $4 \mathrm{~km}$ ) and negative (above $5 \mathrm{~km}$ ) biases. At all launch sites, the mean GEOS-Chem and ozonesonde profiles agree within 1- $\sigma$ standard deviation of the mean at each level, with the model and observations showing comparable variability.

Figure 4 shows the variability in the absolute differences between model ozone profiles co-located to the time and lo- cation of each ozonesonde profile (Table 1). In general, the biases are within $\pm 30 \mathrm{ppbv}( \pm 50 \%)$ throughout the troposphere at each site. Those sites noted above for showing a relatively higher bias in the PBL, i.e. Bratt's Lake, Egbert, Walsingham, and Yarmouth, all show a persistent positive model bias below $2 \mathrm{~km}$ throughout the BORTAS-A campaign period although the biases at Egbert are shown to be lower than at the other three sites. The overestimate in the model ozone mixing ratios in the PBL shows peak values at the surface for all sites apart from Yarmouth, where the peak bias appears to be between 500 and $1500 \mathrm{~m}$, also shown in Fig. 3. Differences in the free troposphere at each launch site show a mixture of positive and negative biases over the course of the campaign period. The mean and median biases at each site are shown in Table 1. The largest mean positive biases are seen at Walsingham, Egbert, Sable Island, Yarmouth, and Bratt's Lake and correspond to biases relative to the observations of $27.2 \%, 20.1 \%, 10.7 \%, 10.1 \%$, and $16.7 \%$ respectively. These relatively large mean positive biases can be attributed to one or two profiles showing a substantially larger positive model bias throughout the troposphere. Smaller mean biases at the other launch sites suggest that relatively large biases between individual model and ozonesonde profiles are more episodic and localised in nature. At Goose Bay and Montreal, the mean relative biases are $4.2 \%$ and $4.7 \%$ respectively.

Differences between the model ozone distribution and the ozonesonde measurements can potentially be attributed to 
Bratts Lake, SK

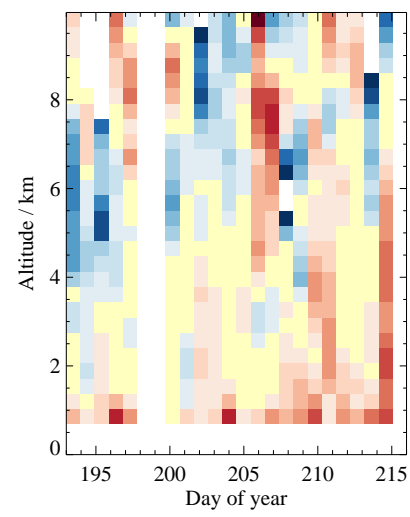

Goose Bay, NL

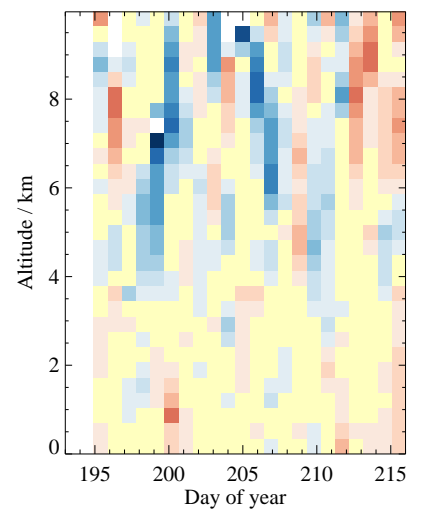

Egbert, ON

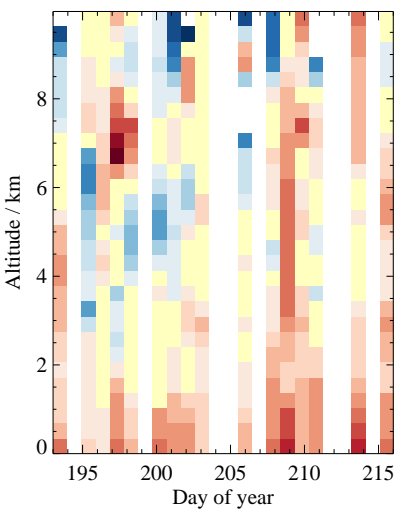

Sable Island, NS

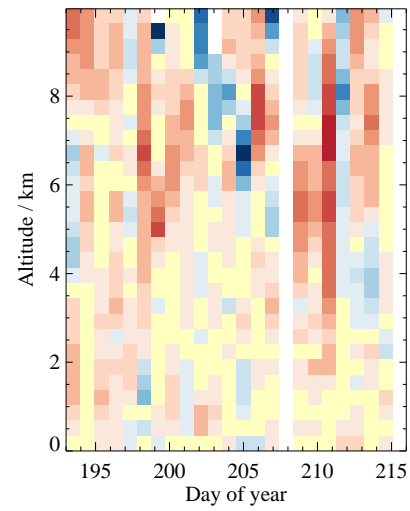

Walsingham, ON

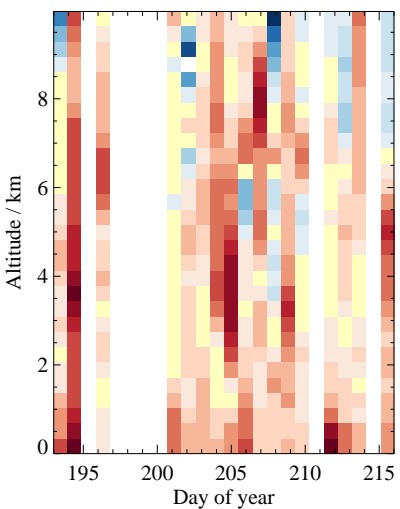

Yarmouth, NS

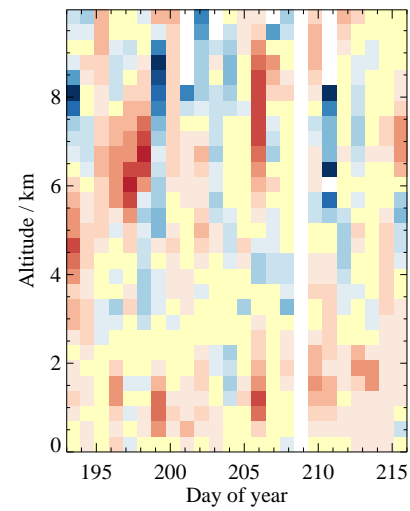

Montreal, QC

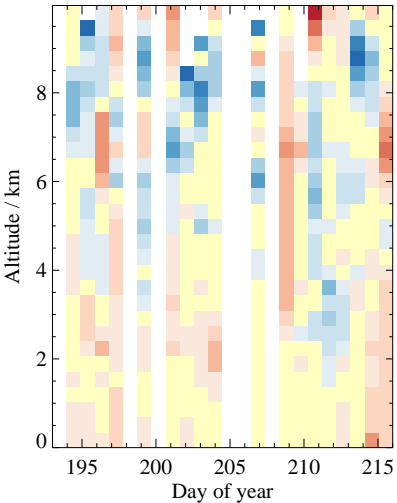

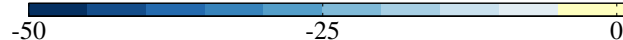

25

[ppbv]

Fig. 4. Time-height cross-sections of the daily ozone differences between GEOS-Chem and ozonesonde profiles over each of the ozonesonde launch sites (Table 1) during the BORTAS-A measurement campaign (12 July to 4 August 2010). White indicates no data present.

small-scale vertical structures which can be measured by the ozonesondes and which are not properly resolved by the model. The inability of the model to capture these structures could be related to the relatively coarse vertical resolution of the model levels (approximately $0.7 \mathrm{~km}$ in the free troposphere and $1 \mathrm{~km}$ in the upper troposphere), the coarse horizontal resolution of the model, or missing emissions/processes in the model. The potential for attributing these differences to the model emissions, transport, and chemistry will be assessed in Section 5.

\subsection{GEOS-Chem vs. Pico Mountain Observatory data}

Measurements of ozone and other trace gas $\left(\mathrm{CO}, \mathrm{NO}, \mathrm{NO}_{2}\right.$, $\mathrm{NO}_{\mathrm{y}}, \mathrm{NMHC}$ ) and aerosol species were made at the Pico Mountain Observatory throughout the summer of 2010 in support of BORTAS-A. The Pico Mountain Observatory is situated on the peak of Mt. Pico in the Azores in the midAtlantic, $38.47^{\circ} \mathrm{N}, 28.40^{\circ} \mathrm{W}$, at an altitude of $2,225 \mathrm{~m}$ (Hon- rath et al., 2004; Helmig et al., 2008) and has considerable potential for sampling photochemically aged air originating from boreal biomass burning sources. We evaluate time series of model ozone, $\mathrm{CO}$, and $\mathrm{NO}_{\mathrm{x}}$ output against the corresponding $1 \mathrm{~h}$ average measurements from the Pico Mountain Observatory. Ozone was measured using a commercial ultraviolet absorption instrument (Thermo Environmental Instruments, Inc., Franklin Massachusetts, Model 49C) (Owen et al., 2006; Helmig et al., 2008). These data have a precision of smaller than $1 \mathrm{ppbv}$ and an accuracy of less than $\pm 1-2 \%$ similar to the re-calibrated accuracy of $\pm 3 \%$ previously reported for $30 \mathrm{~min}$ averaged ozone data. Measurements of $\mathrm{CO}$ were made using a modified commercial nondispersive infrared absorption instrument (Thermo Environmental, Inc., Model 48C-TL), calibrated daily with standards referenced to the NOAA GMD standard (Owen et al., 2006). Owen et al. (2006) reported the 2- $\sigma$ precision and accuracy of 30 -min average $\mathrm{CO}$ data to be be $\pm 3 \mathrm{ppbv}$ and $\pm 6 \%$ respectively. $\mathrm{NO}_{\mathrm{x}}\left(\mathrm{NO}\right.$ and $\left.\mathrm{NO}_{2}\right)$ was determined by 


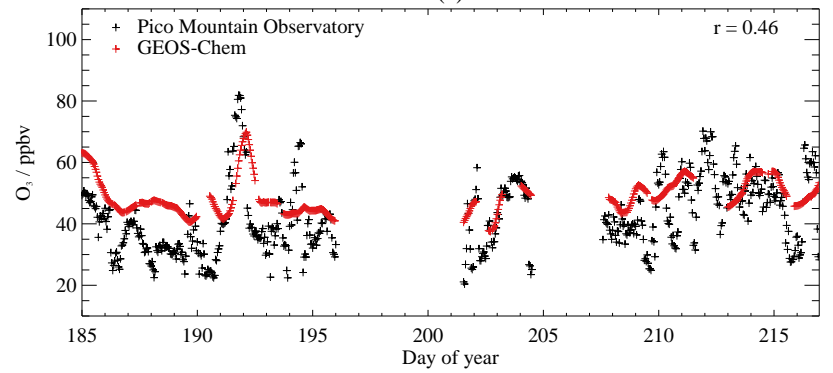

(b)

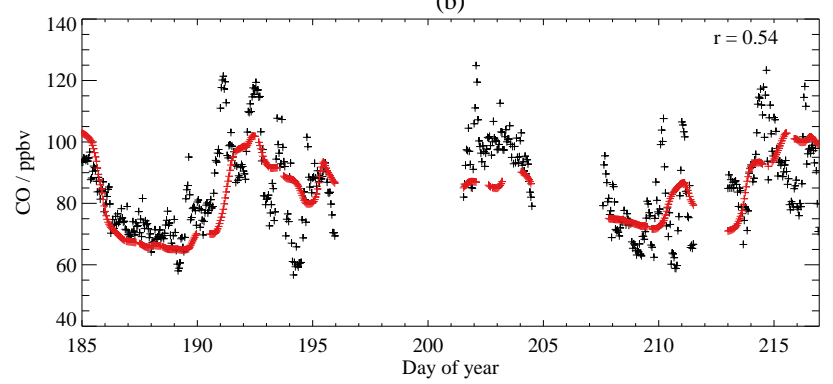

(c)

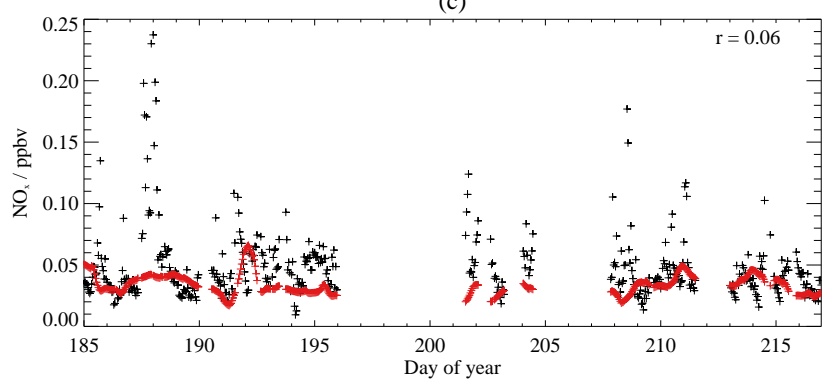

Fig. 5. Time series of (a) ozone, (b) $\mathrm{CO}$, and (c) $\mathrm{NO}_{\mathrm{x}}$ measured at the Pico Mountain Observatory (black symbols), and the co-located model output (red symbols), from 4 July to 4 August 2010 inclusive. The correlation coefficient, $r$, between the observed and model time series is given in each plot.

an automated $\mathrm{NO}_{\mathrm{x}, \mathrm{y}}$ system developed at Michigan Technological University as described by Val Martin et al. (2006). The 2- $\sigma$ precision of 30-min average $\mathrm{NO}_{\mathrm{x}}$ data from this system has been reported to be less than $14 \mathrm{pptv}$ with a potential bias of 4 pptv (Val Martin et al., 2006).

Figure 5 shows the time series of $1 \mathrm{~h}$ average ozone, CO, and $\mathrm{NO}_{\mathrm{x}}$ mixing ratios measured at the Pico Mountain Observatory between 4 July and 4 August 2010 inclusive, and the time series of the corresponding model outputs, colocated in time, elevation, and geographical coordinates, to each measured value. The ozone measurements, shown in Fig. 5a, over this time period are all within the range of 20.4 to $81.8 \mathrm{ppbv}$ and have a mean of $42.3 \mathrm{ppbv}$ with a standard deviation of $11.9 \mathrm{ppbv}$. The model ozone timeseries tends to be at the higher end of the measured values and shows less variability reflected in a mean of $49.6 \mathrm{ppbv}$ in the range 37.8 to $71.0 \mathrm{ppbv}$ and a standard deviation of $6.0 \mathrm{ppbv}$. The mean relative bias between the model and observed ozone is $6.8 \mathrm{ppbv}(14 \%)$ relative to the observations and is comparable to the mean model biases relative to the ozonesonde measurements presented in the previous section. The model only captures approximately $22 \%$ of the observed variability $(r=0.47)$ reflecting the limited ability of the coarse horizontal resolution of the model output to capture the observed variability. The model does capture some of the higher observed peak values, for example on days 192 (11 July), 204 (23 July), and 214 (2 August). Figure 5b shows that the model generally captures the observed $\mathrm{CO}$ trend with a correlation coefficient of 0.55 and mean relative bias between the model and observations of $-1.5 \mathrm{ppbv}(-1.9 \%)$. The comparison between the model and observed $\mathrm{NO}_{\mathrm{x}}$, Fig. $5 \mathrm{c}$, generally shows agreement at low mixing ratios (values between 3 and 5 pptv) but with a mean bias of -0.015 ppbv and correlation coefficient of 0.06 indicating the limited ability of the model to capture the relatively large observed variability, particularly around days 188 (7 July), 202 (21 July), and 209 (28 July). The standard deviation of the observed $\mathrm{NO}_{\mathrm{x}}$ is $0.032 \mathrm{ppbv}$ compared to a standard deviation of $0.009 \mathrm{ppbv}$ for the model $\mathrm{NO}_{\mathrm{x}}$.

\subsection{GEOS-Chem vs. satellite observations}

We extend the evaluation of the model ozone distribution across North America and the North Atlantic with a comparison against tropospheric ozone profiles retrieved from nadir viewing infrared satellite instruments. Satellite observations are beneficial to the analysis presented here as they provide data over large spatial scales, however the data can be noisy and difficult to interpret without a model. The model ozone distribution is compared against tropospheric ozone observations from the Tropospheric Emission Spectrometer (TES) and the Infrared Atmospheric Sounding Instrument (IASI). Ozone profiles retrieved from satellite measurements are an estimate of the atmospheric state which is generally expressed as follows:

$\hat{\mathbf{x}}=\mathbf{x}_{\mathrm{a}}+\mathbf{A}\left(\mathbf{x}-\mathbf{x}_{\mathrm{a}}\right)+\varepsilon$

where $\hat{\mathbf{x}}$ is the retrieved ozone profile, $\mathbf{x}_{\mathrm{a}}$ is the a priori profile applied in the retrieval, $\mathbf{x}$ is the true ozone profile, $\mathbf{A}$ is the averaging kernel, and $\varepsilon$ is the measurement noise. Variables with bold lower case characters are vectors and those with bold upper case characters are matrices. The averaging kernels provide the sensitivity of the retrieved state to the true state of the atmosphere. The trace of the averaging kernel matrix gives a measure of the number of independent pieces of information available in the measurements, more commonly referred to as the degrees of freedom for signal (DOFS) (Rodgers, 2000). Ozone profile retrievals from the TES and IASI satellite datasets considered here are expressed in terms of natural logarithm of volume mixing ratio $(\ln (\mathrm{VMR}))$ and partial column VMR, respectively. Comparison of the model ozone output against satellite data is presented in terms of $\ln (\mathrm{VMR})$. The IASI averaging kernels 

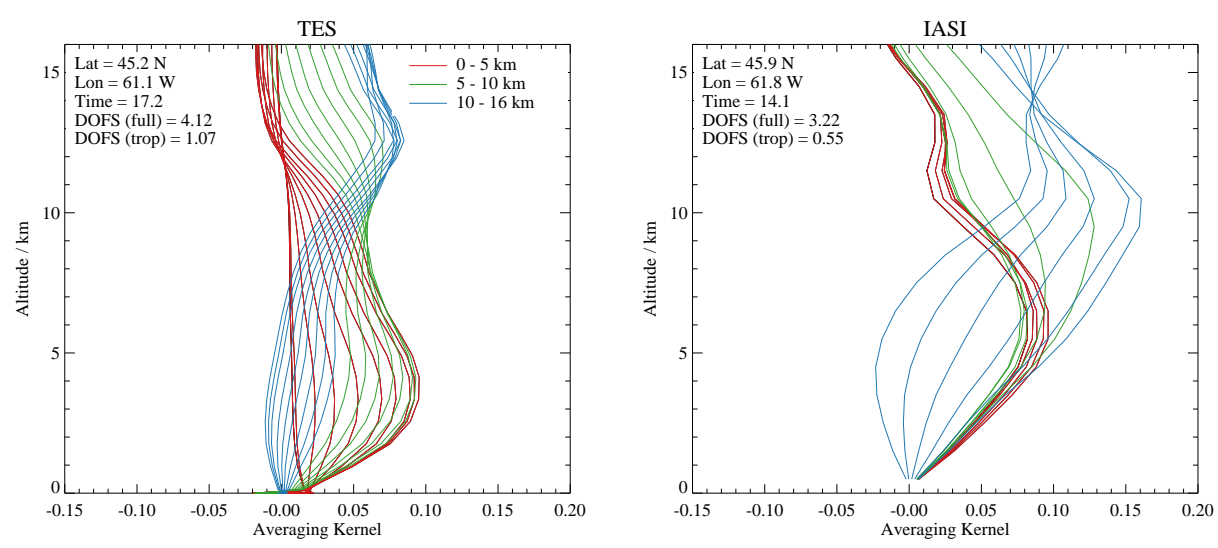

Fig. 6. Averaging kernels (unitless) for ozone profile retrievals made by TES and IASI co-located to Halifax, NS on 16 July 2010.

are converted from partial column VMR to $\ln$ (VMR) following Appendix A of Zhang et al. (2010). For a retrieval in $\ln$ (VMR), Eq. (1) can be written:

$$
\ln \hat{\mathbf{x}}=\ln \mathbf{x}_{\mathrm{a}}+\mathbf{A}^{\prime}\left(\ln \mathbf{x}-\ln \mathbf{x}_{\mathrm{a}}\right)+\varepsilon^{\prime}
$$

Letting $x_{i}$ denote the VMR for layer $i$, which is the $i$-th element of $\mathbf{x}$, and assuming that the difference between $x_{i}$ and $x_{\mathrm{a}, \mathrm{i}}$ is relatively small so that

$\ln x_{i}-\ln x_{\mathrm{a}, \mathrm{i}} \approx \frac{x_{i}-x_{\mathrm{a}, i}}{x_{\mathrm{a}, i}}$

with the same relationship holding between $\hat{x}_{i}$ and $x_{\mathrm{a}, i}$. The elements $a_{i j}^{\prime}$ of the averaging kernel for a $\ln (\mathrm{VMR})$ retrievel $\mathbf{A}^{\prime}$ are then related to the elements $a_{i j}$ of the averaging kernel for a partial column VMR retrieval $\mathbf{A}$ by:

$a_{i, j}^{\prime}=\left(\frac{x_{\mathrm{a}, i}}{x_{\mathrm{a}, \mathrm{j}}}\right) a_{i, j}$

Figure 6 shows averaging kernels for ozone profiles retrieved from the TES and IASI data for a cloud-free scene close to Halifax, NS, on 16 July 2010. The IASI averaging kernels have been converted from partial column VMR to $\ln (\mathrm{VMR})$ using Eq. (4). The averaging kernels are colour coded to indicate the relative sensitivities of retrieval levels in different layers of the atmosphere: $0-5 \mathrm{~km}$ (red); $5-10 \mathrm{~km}$ (green); and $10-16 \mathrm{~km}$ (blue).

\subsection{1 $\mathrm{TES} \mathrm{O}_{3}$}

The TES instrument (Beer et al., 2001) is a high resolution imaging infrared Fourier-transform spectrometer (FTS), launched aboard the NASA EOS Aura satellite in July 2004. The Aura satellite is in a polar Sun-synchronous orbit with a repeat cycle of 16 days. TES utilises a nadir-viewing geometry and an instrument field-of-view at the surface of $8 \mathrm{~km} \times 5 \mathrm{~km}$ to observe spectral radiances in the range 650 $3050 \mathrm{~cm}^{-1}$ at an apodized spectral resolution of $0.1 \mathrm{~cm}^{-1}$.
Geophysical parameters are retrieved from the measured radiances based using a Bayesian framework that solves a constrained least squares problem (Bowman et al., 2006) on a forward model grid with 67 vertical levels (TES Science Team, 2009) with a thickness of approximately $0.6-0.7 \mathrm{~km}$ in the troposphere. The TES data were filtered based on the mean and root mean square of the radiance residual and on the cloud top pressure of each profile, following Parrington et al. (2008) and TES Science Team (2009). We use TES global survey level 2 data version 4 (V004), geographical coverage of these data during the summer of 2010 did not extend poleward of $50^{\circ} \mathrm{N}$. TES V004 ozone profile retrievals were validated against ozonesondes during the spring and summer phases of ARCTAS and found to be biased high in the troposphere by up to $15 \%$ (Boxe et al., 2010), comparable to the 3-10 ppbv bias reported for the V002 retrievals at northern mid-latitudes (Nassar et al., 2008). TES ozone profile retrievals have been used in a number of studies evaluating biomass burning outflow in the boreal regions over Siberia (Verma et al., 2009) and North America (Alvarado et al., 2010; Boxe et al., 2010), and outflow from African biomass burning over the Atlantic Ocean (Jourdain et al., 2007) and Indonesia (Bowman et al., 2009). Ozone profiles retrieved from the TES data, for cloud-free conditions over the North Atlantic, are typically characterized by the averaging kernels shown in the left-hand plot of Fig. 6. A DOFS value of 1.07 for the troposphere (for a tropopause defined as the $120 \mathrm{ppbv}$ ozone isopleth), compared to a value of 4.12 for the full profile, indicates that there is a single piece of independent information retrieved with the averaging kernels for the $0-5 \mathrm{~km}$ atmospheric layer (red lines in Fig. 6) showing the peak sensitivity to be between 3 and $4 \mathrm{~km}$.

Figure 7 shows the comparison of the GEOS-Chem and TES ozone mid-tropospheric distribution $(600-400 \mathrm{hPa}$, approximately $4-6 \mathrm{~km}$ ) averaged over the BORTAS-A campaign period over North America and the North Atlantic. The model output was sampled at the time and location of each retrieved TES ozone profile and incorporates the TES 


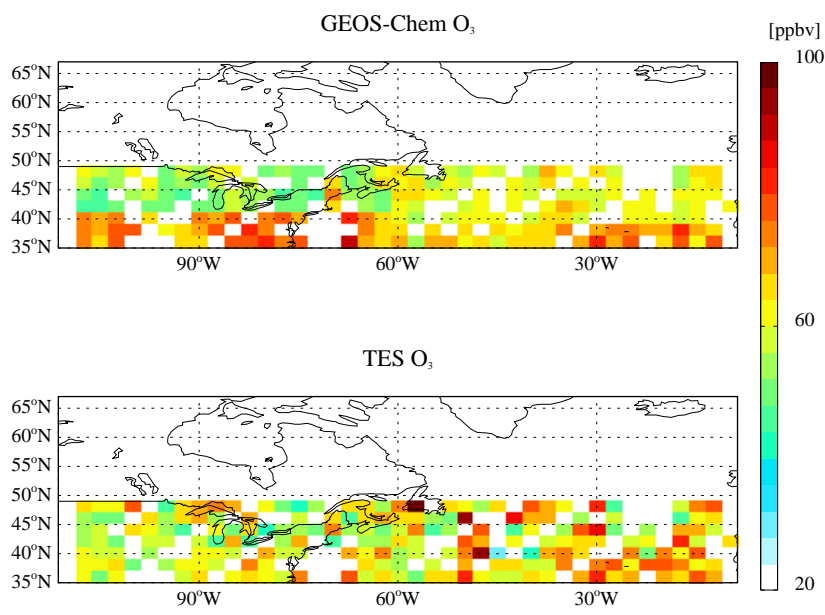

GEOS-Chem - TES

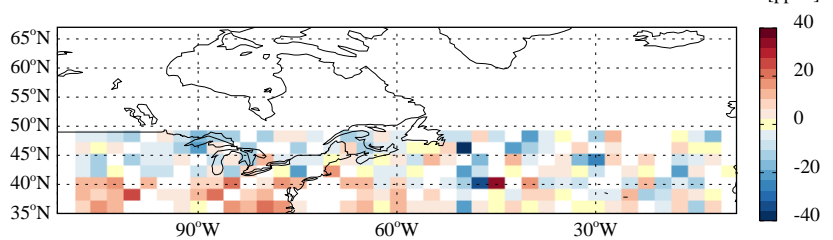

Fig. 7. Comparison of the mean mid-tropospheric $(600-400 \mathrm{hPa})$ ozone distributions modelled by GEOS-Chem and observed by the Tropospheric Emission Spectrometer and the difference (model minus observed). The model ozone profiles have been smoothed by the TES averaging kernels and the TES bias has been removed as described in the text. The plots show the mean daytime ozone averaged over 12 July to 4 August 2010.

observation operator (Jones et al., 2003). A bias of $+7.5 \%$, calculated as the mean of the biases reported in Table 4 of Boxe et al. (2010), excluding those from Barrow, is removed from the TES ozone profiles and is assumed to be constant throughout the troposphere. This bias is comparable with the bias calculated for the model compared to the ozonesonde and Pico Mountain Observatory data presented earlier. The bottom panel of Fig. 7 shows the GEOSChem minus TES ozone difference. The ozone output from the model sampled in the TES observation space shows the highest mixing ratios equatorward of $40^{\circ} \mathrm{N}$ and centred over the eastern US and North Atlantic Basin comparable to the model mixing ratios shown in Fig. 2b. Across the Atlantic Ocean, the model generally shows moderate (approx. $60 \mathrm{ppbv}$ ) ozone mixing ratios with increased values eastward of $30^{\circ} \mathrm{W}$ and equatorward of $40^{\circ} \mathrm{N}$. Relatively high ozone mixing ratios ( $>75 \mathrm{ppbv}$ ) over the Great Lakes region and eastern Atlantic Ocean are also evident although not as prominent as shown for the $500 \mathrm{hPa}$ pressure level in Fig. 2b. The TES observations do not show such a prominent latitudinal gradient in the ozone mixing ratio, although they do capture the outflow from the North American PBL, with relatively high ozone values shown across the domain.
The TES data show the highest ozone mixing ratios over the Atlantic Ocean, at approximately $50^{\circ} \mathrm{W}$ and westward of $30^{\circ} \mathrm{W}$. The biases between the GEOS-Chem and TES ozone distributions are approximately evenly distributed between positive and negative values across North America and the North Atlantic. The mean and median of the model minus TES ozone bias across the domain shown in Fig. 7 are -0.3 and $-0.1 \mathrm{ppbv}$ in the range -40.8 to $+34.6 \mathrm{ppbv}$.

\subsubsection{IASI $\mathrm{O}_{3}$}

The IASI instrument (Clerbaux et al., 2009) is a Fourier transform spectrometer with a $2 \mathrm{~cm}$ optical path difference covering a spectral range from $645-2760 \mathrm{~cm}^{-1}$ at an apodized spectral resolution of $0.5 \mathrm{~cm}^{-1}$. It observes the atmosphere in the nadir with an instantaneous field-of-view of four $12 \mathrm{~km}$ diameter pixels at the sub-satellite point scanned in a west-east swath of approximately $2200 \mathrm{~km}$, perpendicular to the satellite orbit track. IASI was launched on the European Metop satellite, which is in a sun-synchronous orbit with an equator crossing at 0930 and 2130 local time, in October 2007. Tropospheric ozone profiles are retrieved from the IASI radiance measurements with the FORLI retrieval algorithm (version 20100406) based on using an optimal estimation methodology developed for nadir viewing thermal infrared sounders (Coheur et al., 2005; Boynard et al., 2009) on a retrieval grid with 40 vertical levels and vertical resolution of $1 \mathrm{~km}$ in the troposphere. Ozone profiles retrieved from the IASI data were found to be biased low by approximately $-8 \%$ in the lower troposphere, below $6 \mathrm{~km}$, compared to ozonesondes at northern mid-latitudes in 2008 (Dufour et al., 2011). IASI data were used in studies of biomass burning outflow in the Mediterranean during the summer of 2007 (Coheur et al., 2009). The averaging kernels for an IASI ozone profile retrieval are shown in the right-hand plot of Fig. 6. In contrast to the TES ozone averaging kernels, an ozone profile retrieved from the IASI measurements gives lower values of DOFS for both the full and tropospheric profiles (3.33 and 0.55 respectively) with the sensitivity for the $0-5 \mathrm{~km}$ layer peaking at approximately $6 \mathrm{~km}$. The differences in sensitivity between the IASI and TES ozone profile retrievals reflects the relatively coarse resolution of the IASI spectra compared to TES.

Figure 8 shows the comparison of the GEOS-Chem and IASI mid-tropospheric ozone distributions $(600-400 \mathrm{hPa}$, approximately 4-6 km) averaged over the BORTAS-A campaign period over North America and the North Atlantic. Retrieved IASI ozone profiles with tropospheric DOFS less than 0.5 have been filtered out of the analysis. The model output was sampled at the time and location of each valid retrieved IASI ozone profile and smoothed with the IASI averaging kernels. The IASI averaging kernels are converted from a partial column retrieval to $\ln (\mathrm{VMR})$ using Equation 4 as described above. A mean bias profile that linearly increases in altitude from $-15 \%$ at the lowest retrieval level to $-5 \%$ 


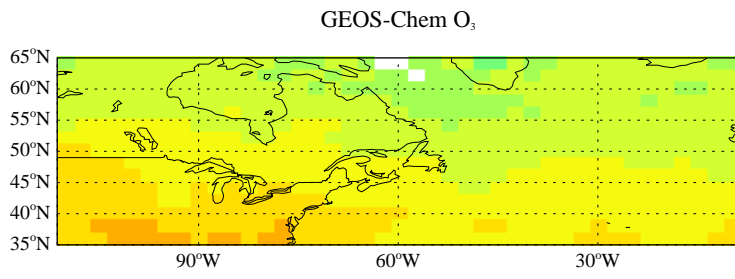

$\mathrm{IASI}_{3}$

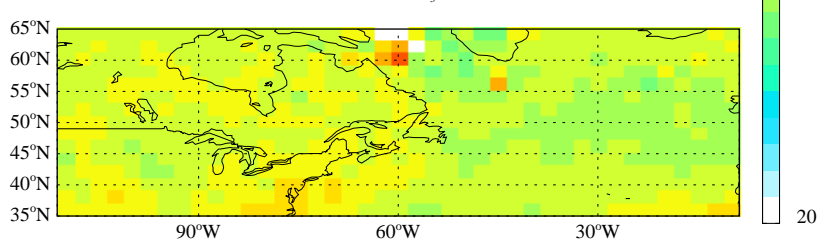

GEOS-Chem - IASI

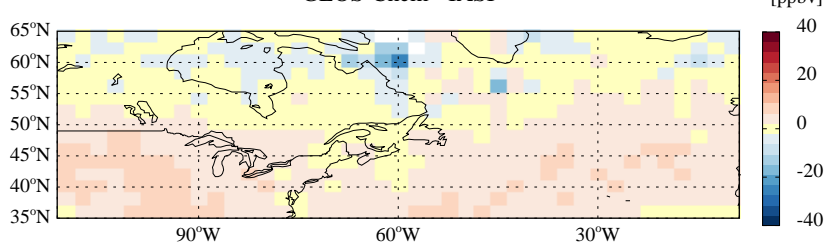

Fig. 8. Same as Fig. 7 for the ozone distribution observed by the Infrared Atmospheric Sounding Instrument, and the model ozone profiles have been smoothed by the IASI averaging kernels and the IASI bias has been removed.

at $8 \mathrm{~km}$, and with values of $0 \%$ and $+10 \%$ at 9 and $10 \mathrm{~km}$ respectively, based on comparison to ozonesonde profiles at northern mid-latitudes in 2008 and consistent with the validation against ozonesondes presented by Dufour et al. (2011), is added to the IASI ozone profiles. The bottom panel of Fig. 8 shows the GEOS-Chem minus IASI ozone difference. The model ozone output sampled in the IASI observation space shows a similar distribution to that shown in Figs. 2 and 7 with the higher ozone mixing ratios (approximately 60 ppbv) across the US, North Atlantic Basin, and eastern Atlantic Ocean. Poleward of $50^{\circ} \mathrm{N}$ smoothing of the model ozone output with the IASI averaging kernels leads to lower ozone values over the North Atlantic Ocean than shown at $500 \mathrm{hPa}$ in Fig. $2 \mathrm{~b}$, centred around $30^{\circ} \mathrm{W}$, due to the peak sensitivity of the IASI ozone retrievals being slightly above this level. At the higher latitudes over Canada moderately high ozone mixing ratios (40-60 ppbv) are shown of similar order of magnitude at $500 \mathrm{hPa}$ in Fig. 2b. The mean ozone distribution observed by IASI shows a similar pattern to that of the GEOS-Chem output sampled in the IASI observation space. The GEOS-Chem minus IASI ozone differences show the model to be higher than the observations over the majority of the geographical region shown. The largest disagreement between the model and IASI are across the central US and central Atlantic Ocean, where the ozone values are at their highest ( $>50-60 \mathrm{ppbv}$ ), and the closest agreement poleward of $50^{\circ} \mathrm{N}$ and eastward of $90^{\circ} \mathrm{W}$, where the ozone mixing ratios are relatively low $(<30 \mathrm{ppbv})$. The mean and median of the model minus IASI ozone bias across North America and the North Atlantic are +1.9 and $+2.3 \mathrm{ppbv}$ in the range -23.5 to +10.4 ppbv.

\section{Adjoint analysis of model inputs}

In the previous section we evaluated the 3-D model tropospheric ozone distribution over North America and the North Atlantic using in situ and satellite observations. Although the model shows reasonable agreement with the observations, with mean biases less than $14 \%$ for all datasets, we want to identify which model processes and parameters need to be changed to give the optimal agreement between the model and observations, assuming that the model transport and chemistry are unbiased. In the following section we analyse the sensitivity of the model ozone distribution to the emission estimates of ozone precursors used in the model and compare their relative influences. We use the GEOSChem adjoint for sensitivity calculations to evaluate the relative contributions of different emissions sources to the model ozone distribution over the North Atlantic and data assimilation to evaluate the $\mathrm{CO}$ emission estimates used by the forward model. The adjoint of GEOS-Chem was first described by Henze et al. (2007) and the version used here includes model code updates to version v8-02-04 of GEOSChem. The model inputs are the same as described for the GEOS-Chem model in Sect. 3. The GEOS-Chem adjoint has previously been applied in model sensitivity studies for global aerosol sources (Henze et al., 2007) and attribution of ozone pollution in the western US (Zhang et al., 2009a), and for inversion of global CO emissions with satellite observations (Kopacz et al., 2010).

The adjoint model approach provides an efficient means for analysing the sensitivity of the model output to each of the model inputs by evaluating the gradient of a cost function $J$ with respect to the input parameters (e.g. emission estimates, initial conditions). For a sensitivity analysis, the cost function can be simply defined as a set of model predictions $g$ of a particular model state variable, e.g. trace gas profile or integrated column amount, $\mathbf{c}$ :

$J=\sum_{\mathbf{c} \in \Omega_{s}} g(\mathbf{c})$

where $\Omega_{\mathrm{s}}$ is the set of times at which the cost function is evaluated.

When observations of a particular state variable $\left(\mathbf{c}_{\mathrm{obs}}\right)$ are available, the cost function balances the model and observed state, and the input parameter, e.g. emission inventory, (p) against a priori knowledge of that parameter $\left(\mathbf{p}_{\mathrm{a}}\right)$, and is generally defined as:

$J=\frac{1}{2} \sum_{\mathbf{c} \in \Omega}\left[\mathbf{H}(\mathbf{c})-\mathbf{c}_{\mathrm{obs}}\right]^{\mathrm{T}} \mathbf{S}_{\mathrm{obs}}^{-1}\left[\mathbf{H}(\mathbf{c})-\mathbf{c}_{\mathrm{obs}}\right]+\frac{1}{2}\left[\mathbf{p}-\mathbf{p}_{\mathrm{a}}\right]^{\mathrm{T}} \mathbf{S}_{\mathrm{p}}^{-1}\left[\mathbf{p}-\mathbf{p}_{\mathrm{a}}\right]$ 
where $\mathbf{H}$ is the observation operator which transforms the model profile into the observation space taking into account the characteristics of the observations (e.g. the averaging kernels for a profile retrieved from satellite data). $\mathbf{S}_{\mathrm{obs}}$ and $\mathbf{S}_{\mathrm{p}}$ are the observational and a priori error covariance matrices respectively and will be described below. $\Omega$ is the domain (in time and space) over which model predictions and observations are available. The superscripts $\mathrm{T}$ and -1 denote matrix transpose and inverse operations respectively.

The optimal solution for the parameter to be estimated minimizes $J$ in Eq. (6) so that the gradient of the cost function with respect to the model state vector is zero:

$\nabla_{\mathbf{c}} J=\frac{\partial J(\mathbf{c})}{\partial \mathbf{c}}=0$

Solution of the optimization problem requires the gradients of $J$ with respect to the model state vector, and these are efficiently calculated using the adjoint method. The derivation of the adjoint of GEOS-Chem is described in detail by Henze et al. (2007).

The adjoint variable at any given timestep is the sensitivity of the cost function with respect to the model state vector (e.g. $\lambda_{c}^{0}=\nabla_{c^{0}} J$ gives sensitivity to initial conditions; $\lambda_{p}^{0}=\nabla_{p} J$ gives sensitivity to other model parameters such as emission estimates).

\subsection{Sensitivity calculations}

The sensitivity of the model tropospheric ozone distribution over the BORTAS-A campaign period to the model input parameters is evaluated using the adjoint of GEOS-Chem described above. The cost function for these adjoint sensitivity calculations, described by Eq. (5), is the sum of the model ozone distribution in the free troposphere (between the top of the PBL and the tropopause, typically $750-250 \mathrm{hPa}$ at northern mid-latitudes) above the three ozonesonde launch sites in Maritime Canada (i.e. Goose Bay, Sable Island, and Yarmouth, see Table 1). The forward and backward simulations are performed from 12 July to 4 August 2010, and the cost function is evaluated at every hour throughout the simulation.

Figure 9 shows the sensitivity of the model ozone distribution over Maritime Canada to the $\mathrm{NO}_{\mathrm{x}}$ emission estimates from biomass burning, lightning, anthropogenic, and combined aircraft, soil and biofuel sources, and $\mathrm{CO}$ emission estimates from biomass burning and anthropogenic sources. The location of the ozonesonde launch sites, where the cost function is initialized, are shown by red triangles. The sensitivities shown have been normalised by dividing the gradient of the cost function by the cost function so that relative influence of the different emission sources can be compared against each other. The largest model ozone sensitivity is to anthropogenic $\mathrm{NO}_{\mathrm{x}}$ emission estimates, centred over the northeastern US and southeastern Canada, in Quebec and Nova Scotia. The influence of the anthropogenic emission
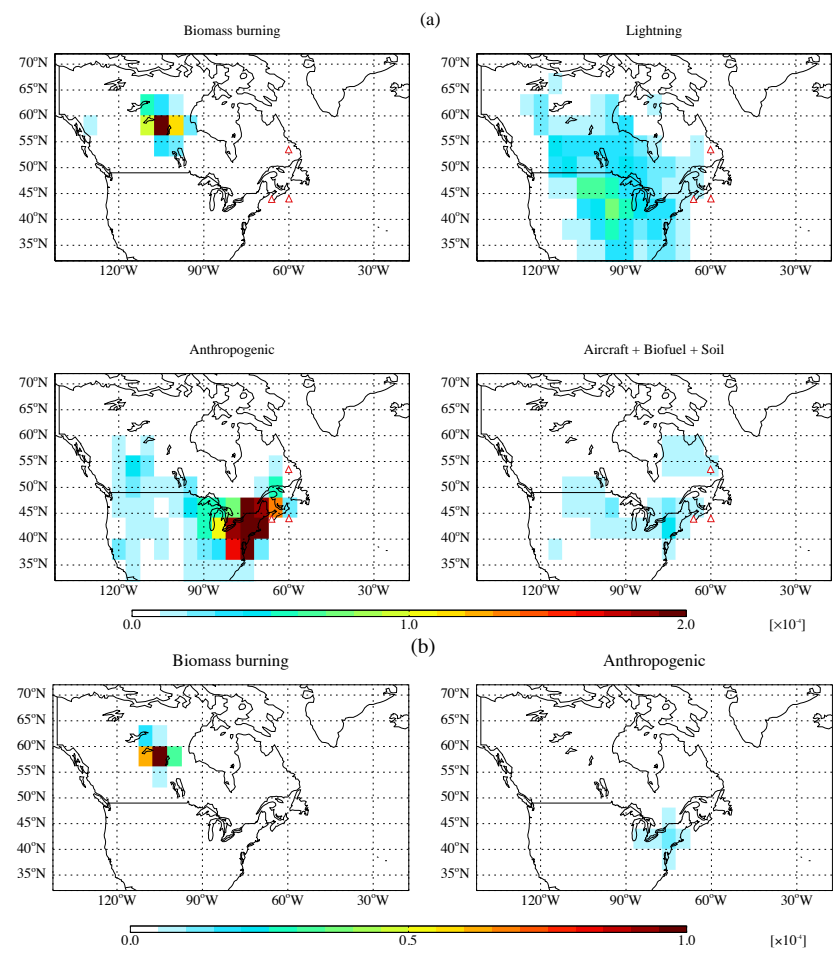

Fig. 9. Normalised cost function sensitivity of model free tropospheric (approximately $750-250 \mathrm{hPa}$ ) ozone profiles over ozonesonde launch sites in Maritime Canada to: (a) $\mathrm{NO}_{\mathrm{x}}$ emissions estimates associated with biomass burning, lightning, anthropogenic, and combined aircraft/biofuel/soil sources; and (b) $\mathrm{CO}$ emissions estimates associated with biomass burning and anthropogenic sources over the BORTAS-A campaign period (12 July to 4 August 2010). The ozonesonde launch site locations (Goose Bay, Sable Island, and Yarmouth from Table 1) are denoted by red triangles in each plot.

estimates extends across North America but the sensitivity is less than half the peak values over the main anthropogenic source regions. We find that biomass burning is the next most significant $\mathrm{NO}_{\mathrm{x}}$ emission source, with the peak sensitivity localised to the main biomass burning region in Central Canada. The adjoint simulation also illustrates (not shown here) some sensitivity of the free tropospheric ozone distribution to biomass burning $\mathrm{NO}_{\mathrm{x}}$ emissions over Alaska and Eastern Siberia, but is greatly reduced compared to the Canadian source. The model ozone shows sensitivity to lightning $\mathrm{NO}_{\mathrm{x}}$ emissions which, although smaller in magnitude compared to the anthropogenic and biomass burning sensitivity, cover a large area of North America with peak sensitivity shown to be over the central US, to the west of the Great Lakes, and extending into the eastern US and Central Canada. The combined sensitivity to $\mathrm{NO}_{\mathrm{x}}$ emissions from other sources (i.e. aircraft, soil, and biofuel) is considerably lower than that for the anthropogenic, biomass burning, and lightning sources. For the CO emissions, shown in Fig. 9b, the largest ozone sensitivity is to the biomass burning sources 


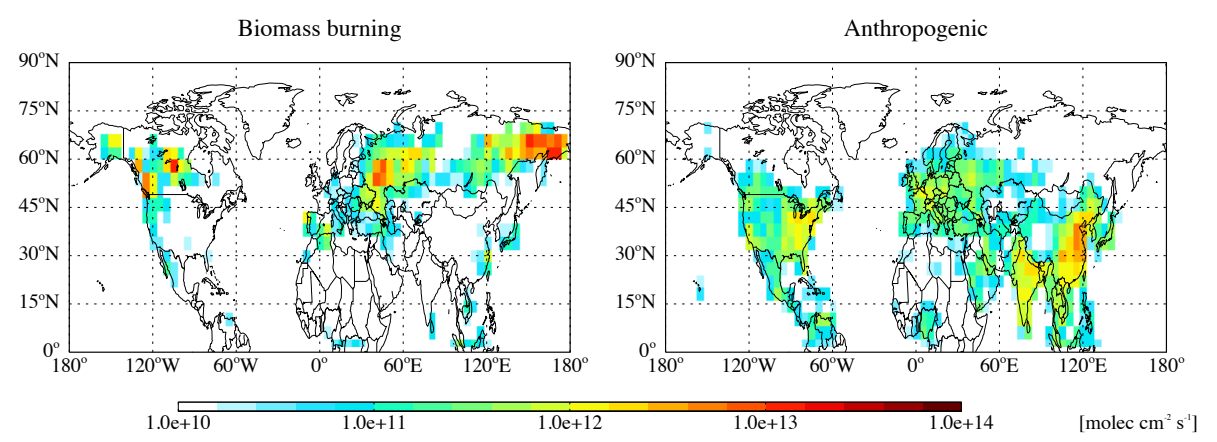

Fig. 10. Mean Northern Hemisphere CO emissions from biomass burning and anthropogenic sources (molecules $\left.\mathrm{cm}^{-2} \mathrm{~s}^{-1}\right)$ averaged over 12 July to 4 August 2010. Biomass burning emissions are from the FLAMBE inventory (Reid et al., 2009). Anthropogenic emissions in the model are as those described in Sect. 3.

in Central Canada. The peak sensitivity to biomass burning $\mathrm{CO}$ emissions is approximately half that of the ozone sensitivity to the biomass burning $\mathrm{NO}_{\mathrm{x}}$ emissions.

Figure 9 highlights some of the key potential sources of uncertainty in the model ozone chemistry and their relative contributions. In the remaining sections of this paper we evaluate ozone precursor emissions from biomass burning sources in order to isolate its associated uncertainty in the model ozone distribution. Although the anthropogenic sources of $\mathrm{NO}_{\mathrm{x}}$ show the largest sensitivities, further quantification of their contribution is beyond the scope of the work presented here and will be evaluated in future work within the context of the BORTAS-B measurement campaign in summer 2011.

\subsection{Biomass burning emissions}

We evaluate the FLAMBE biomass burning emissions used in the model through a global inversion of satellite observations of CO. Although Fig. 9 showed the ozone sensitivity to biomass burning $\mathrm{CO}$ emissions to be smaller than to the $\mathrm{NO}_{\mathrm{x}}$ emissions, $\mathrm{CO}$ has a considerably longer photochemical lifetime, of several weeks compared to several hours for $\mathrm{NO}_{\mathrm{x}}$, making it a more reliable tracer of biomass burning outflow on a global scale. Emissions of $\mathrm{NO}_{\mathrm{x}}$, and other species emitted by biomass burning sources, are related to the the $\mathrm{CO}$ emissions through emission factors (e.g. Andreae and Merlet, 2001) and in this way can be altered by the same scaling determined for $\mathrm{CO}$ from the inversion.

Satellite observations of $\mathrm{CO}$ are available from a number of different platforms and measurement techniques. We use CO observations made by the Measurements Of Pollution In The Troposphere (MOPITT) instrument as they have been extensively used in inversions with GEOS-Chem in previous studies (e.g. Arellano et al., 2006; Fortems-Cheiney et al., 2009; Jones et al., 2009; Kopacz et al., 2009, 2010; Gonzi et al., 2011; Jiang et al., 2011). The MOPITT instrument is a gas correlation radiometer, launched aboard the NASA EOS Terra satellite in December 1999. MOPITT observes the atmosphere in the nadir with a group of four pixels with an instantaneous field-of-view of $22 \mathrm{~km} \times 22 \mathrm{~km}$ at the satellite sub-point, which are scanned across the orbit track in a swath approximately $650 \mathrm{~km}$ wide. The EOS Terra platform is in a Sun-synchronous orbit with a 10.30 local equator crossing time and a repeat cycle of 16 days, which combined with the MOPITT sampling, provides almost global coverage every 3-4 days. A full instrument description is given by Drummond et al. (2010). In this work we use vertical profiles of CO mixing ratio retrieved using version 4 (V4) of the MOPITT operational processing algorithm (Deeter et al., 2010). In this product, CO profiles are based solely on radiances in the thermal infrared $4.7 \mu \mathrm{m}$ band and are retrieved as quantities of $\log _{10}(\mathrm{VMR})$ on a 10 -level vertical pressure grid. Validation of the MOPITT V4 CO retrievals against aircraft flask samples over North America show a bias of approximately $1 \%$ in the lower troposphere and up to $-6 \%$ in the mid-troposphere, with a drift in the bias of between approximately 1 and $2 \%$ per year (Deeter et al., 2010).

Figure 10 shows the mean Northern Hemisphere CO emission estimates from the FLAMBE inventory averaged for the BORTAS-A campaign period. Biomass burning in the boreal regions feature prominently with the largest emissions, in excess of $10^{13}$ molecules $\mathrm{cm}^{-2} \mathrm{~s}^{-1}$, shown in Central Canada, Eastern Siberia, and western Russia. Table 2 shows the total mass of carbon emitted from biomass burning, in the context of other emission sources of CO, over the BORTAS-A campaign period. The mass of carbon emitted is shown for the globe versus the boreal regions (all latitudes poleward of $\left.50^{\circ} \mathrm{N}\right)$, and for the North America $\left(170^{\circ}\right.$ to $50^{\circ} \mathrm{W}, 50^{\circ}$ to $75^{\circ} \mathrm{N}$ ), Central Canada $\left(120^{\circ}\right.$ to $90^{\circ} \mathrm{W}, 52^{\circ}$ to $\left.62^{\circ} \mathrm{N}\right)$, and Eastern Siberia $\left(110^{\circ}\right.$ to $180^{\circ} \mathrm{E}, 50^{\circ}$ to $\left.75^{\circ} \mathrm{N}\right)$ regions defined in Fig. 1. For all regions the biomass burning emissions are the dominant source, accounting for more than $75 \%$ of the total $\mathrm{CO}$ emissions. The total mass of nitrogen emitted as $\mathrm{NO}_{\mathrm{x}}$ from different sources is shown in Table 3 with boreal biomass burning sources accounting for more than $60 \%$ of the total $\mathrm{NO}_{\mathrm{x}}$ emissions over North America, and $80 \%$ over Eastern Siberia. 
Table 2. Total CO emissions over the BORTAS-A campaign period (12 July to 4 August 2010) in units of Tg C. Values in italics have units of $10^{-3} \mathrm{TgC}$.

\begin{tabular}{lccccc}
\hline CO emission source & Global & Boreal & North America & Central Canada & Eastern Siberia \\
\hline Biomass burning & 100.4 & 9.8 & 274.4 & 85.3 & 259.6 \\
Anthropogenic & 31.4 & 0.3 & 7.0 & 1.4 & 1.4 \\
Biofuel & 5.0 & 0.1 & 0.8 & 0.2 & 0.2 \\
Monoterpenes & 3.8 & 0.3 & 13.9 & 1.7 & 6.4 \\
\hline Total & 140.5 & 10.5 & 296.1 & 88.6 & 267.5 \\
\hline
\end{tabular}

Table 3. Total $\mathrm{NO}_{\mathrm{x}}$ emissions over the BORTAS-A campaign period (12 July to 4 August 2010) in units of Gg N. Values in italics have units of $10^{-3} \mathrm{Gg} \mathrm{N}$.

\begin{tabular}{lccccc}
\hline $\mathrm{NO}_{\mathrm{x}}$ emission source & Global & Boreal & North America & Central Canada & Eastern Siberia \\
\hline Biomass burning & 1552.4 & 155.0 & 3779.0 & 1132.7 & 4404.6 \\
Anthropogenic & 1670.8 & 25.9 & 623.3 & 196.3 & 86.7 \\
Lightning & 765.5 & 26.3 & 961.0 & 174.6 & 685.0 \\
Soil & 574.7 & 12.4 & 533.0 & 34.0 & 203.6 \\
Fertilizer & 81.7 & 1.5 & 17.4 & 0.2 & 3.2 \\
Aircraft & 35.1 & 1.4 & 101.1 & 3.5 & 9.1 \\
Biofuel & 62.4 & 1.7 & 11.9 & 2.6 & 2.8 \\
\hline Total & 4742.7 & 224.3 & 6026.6 & 1543.8 & 5395.0 \\
\hline
\end{tabular}

Previous studies using the FLAMBE inventory have shown the $\mathrm{CO}$ emissions to be a factor of approximately two too high when compared to aircraft observations from the spring (Fisher et al., 2010) and summer (Alvarado et al., 2010) phases of the ARCTAS campaign in 2008. Optimizing the $\mathrm{CO}$ emissions used in the model simulations presented earlier in this work is desirable for two reasons: (1) quantifying the amount of ozone production and transport from the biomass burning source; and (2) reducing the uncertainty in the model ozone distribution associated with the reported over-estimation of the biomass burning source. We optimized the monthly $\mathrm{CO}$ emissions estimates for May-August 2010 using an inverse modelling approach with the GEOSChem adjoint described above. In the inversion MOPITT CO observations are averaged over the $4^{\circ}$ latitude $\times 5^{\circ}$ longitude horizontal resolution of the model. The observation error covariance matrix $\mathbf{S}_{\mathrm{obs}}$ is defined as a uniform error of $20 \%$ and is assumed to be diagonal at the $4^{\circ} \times 5^{\circ}$ resolution used for the inversion (Kopacz et al., 2010). The a priori error covariance matrix $\mathbf{S}_{\mathrm{a}}$ includes a uniform error of $50 \%$ for combustion sources and $25 \%$ for the global oxidation source following Kopacz et al. (2010), and are assumed to be uncorrelated. The CO emissions are assumed to be optimized when the inversion has converged to a solution or when the twentieth iteration of the inversion process has been reached, when the change in the cost function is less than $1-2 \%$.
Figure 11 shows the results of the $\mathrm{CO}$ inversion for July 2010. Figure 11a and b show the a priori and a posteriori Northern Hemisphere emissions, in units of molecules $\mathrm{cm}^{-2} \mathrm{~s}^{-1}$, for the combined contributions from biomass burning, anthropogenic, biofuel, and monoterpene sources. Figure $11 \mathrm{c}$ shows the unitless scaling factors derived from the MOPITT CO inversion. In general the CO inversion decreases the total $\mathrm{CO}$ emissions across the Northern Hemisphere, reflected by scaling factors of less than 1 in Fig. 11c. The distribution of the scaling factors reflects the location of the a priori $\mathrm{CO}$ emissions with the lower values of the scaling factors (i.e. where the emissions are estimated to have the largest over-estimate) coincident to the biomass burning emissions sources, particularly in the boreal regions. The mean scaling factor over the Northern Hemisphere is 0.86 in the range 0.09 to 1.15 and the total $\mathrm{CO}$ emitted from biomass burning over the BORTAS-A measurement period is reduced by $47 \mathrm{Tg} \mathrm{C}(53 \%)$ from the value reported in Table 2, with the largest decrease over sub-tropical Africa. Mean scaling factors for the boreal region and the North America, Central Canada, and Eastern Siberia regions defined for Fig. 1 are 0.89 (in the range $0.12-1.02), 0.92(0.22-1.02), 0.72(0.22-$ $0.99)$, and $0.82(0.20-1.01)$ respectively reducing the total $\mathrm{CO}$ emitted from biomass burning sources in these regions during BORTAS-A by $1.2(12 \%), 66.5$ (24\%), 36.5 (43\%), and $9.6 \mathrm{TgC}(4 \%)$ respectively. The mean scaling factor of 0.72 for the Central Canada region is almost double the scaling factor of $37.5 \%$ applied to the amount of biomass 
(a)

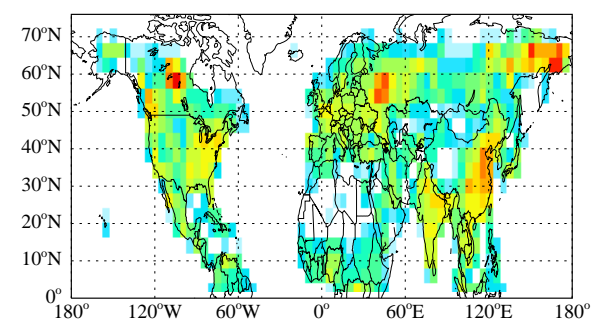

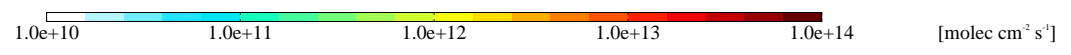

(c)

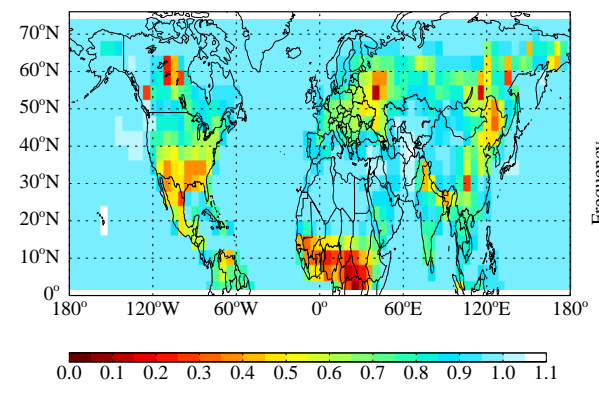

(b)

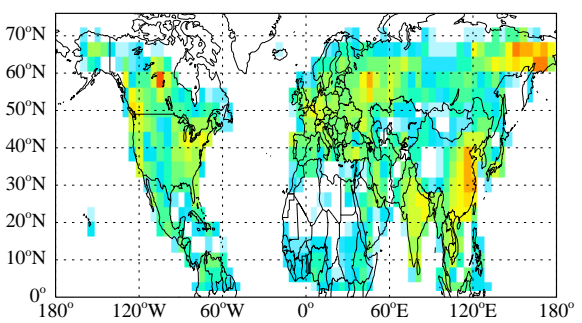

(d)

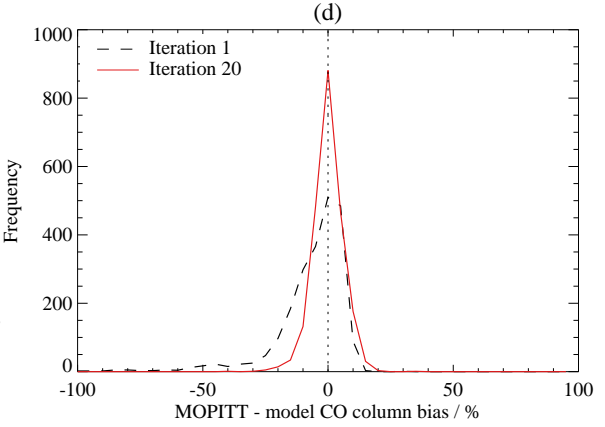

Fig. 11. Mean Northern Hemisphere a priori and a posteriori CO emissions from all sources and scaling factors derived from the assimilation of MOPITT V4 CO observations for July 2010. Plots (a) and (b) respectively show the a priori and a posteriori CO emissions and plot (c) shows the scaling factors. Plot (d) shows histograms of the mean MOPITT minus model biases averaged over the northern extra-tropics for the first (black dashed line) and twentieth (red solid line) iterations of the MOPITT inversion.

consumed to match model CO profiles, using FLAMBE, to aircraft measurements taken during the ARCTAS summer campaign in 2008 (Alvarado et al., 2010). The scaling factor applied by Alvarado et al. (2010) is within the range of scaling factors calculated for this region from the MOPITT $\mathrm{CO}$ inversion. Figure 11d shows the histogram of the relative bias between the MOPITT and model CO total columns after the first (black dashed line) and twentieth (red solid line) iterations of the $\mathrm{CO}$ inversion. The mean MOPITT minus model $\mathrm{CO}$ bias after the first iteration is $-4.0 \%$ with a standard deviation of $14.7 \%$, which is reduced to $+2.5 \%$ with a standard deviation of $5.9 \%$ after the twentieth iteration, indicating an improved fit of the model $\mathrm{CO}$ to the observations. The distribution of the $\mathrm{CO}$ bias after the twentieth iteration shows a higher frequency of zero bias compared to the distribution after the first iteration.

\subsection{Impact on model ozone and precursor distributions}

We evaluate the sensitivity of the model ozone distribution to the FLAMBE biomass burning inventory using revised biomass burning emission estimates that are optimised to agree with MOPITT CO column observations as described in the previous section. The scaling factors derived from the MOPITT inversion performed at $4^{\circ} \times 5^{\circ}$ horizontal resolution above are first regridded per unit area to a resolution of $2^{\circ} \times 2.5^{\circ}$. The total carbon emissions from the a priori
FLAMBE inventory at each timestep are multiplied by the monthly scaling factors and the $\mathrm{CO}, \mathrm{NO}_{\mathrm{x}}$, and other biomass burning emissions are in turn modified through the emissions factors from Andreae and Merlet (2001). Emissions of nonbiomass burning sources are not affected. Figures 10 and 11 show that $\mathrm{CO}$ emission estimates from biomass burning and anthropogenic sources across the Northern Hemisphere are generally distinct from each other and that the anthropogenic emission estimates dominate in regions where they coincide.

Figure 12 shows the mean model distributions of ozone, $\mathrm{CO}, \mathrm{PAN}$, and $\mathrm{NO}_{\mathrm{x}}$ at $500 \mathrm{hPa}$ averaged over the BORTASA campaign period from the simulation with the scaled FLAMBE inventory (top row) and the change in the model tracer distributions over the simulation with the original biomass burning emission estimates (bottom row). The model tracer distributions with the scaled biomass burning emissions all show a decrease across North America and the North Atlantic, apart from $\mathrm{NO}_{\mathrm{x}}$, which shows a decrease across North America and almost zero difference over the Atlantic Ocean eastward of $60^{\circ} \mathrm{W}$. All tracers show the largest changes (as much as $-3 \mathrm{ppbv}(-8 \%$ ) for ozone, $-20 \mathrm{ppbv}$ $(-30 \%)$ for $\mathrm{CO},-50 \mathrm{pptv}(-40 \%)$ for PAN, and $-20 \mathrm{pptv}$ $(-40 \%)$ for $\mathrm{NO}_{\mathrm{x}}$ ) localised to the boreal biomass burning sources in Central Canada. For the ozone, CO, and PAN distributions the largest differences are shown to extend poleward from the main source region in northern Saskatchewan and eastward across Hudson Bay to northeast Canada and 
$\mathrm{O}_{3}$

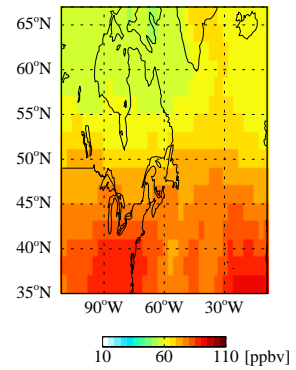

$\mathrm{O}_{3}$ difference

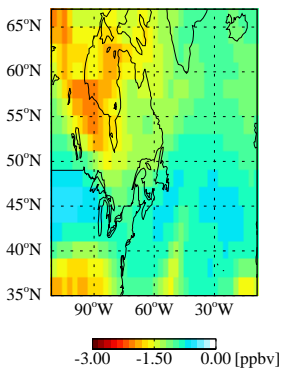

$\mathrm{CO}$

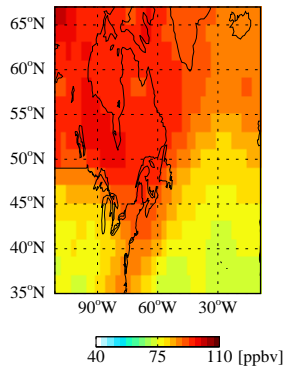

CO difference

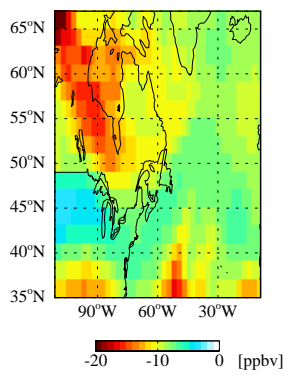

PAN

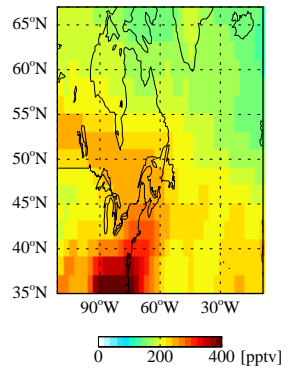

PAN difference

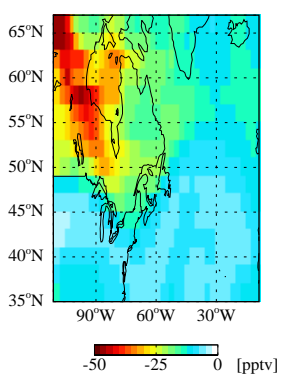

$\mathrm{NO}$

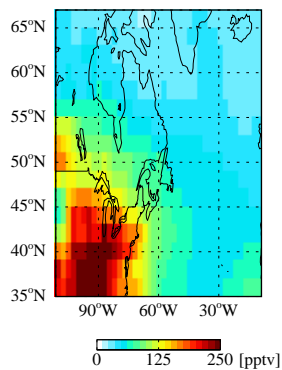

$\mathrm{NO}_{x}$ difference

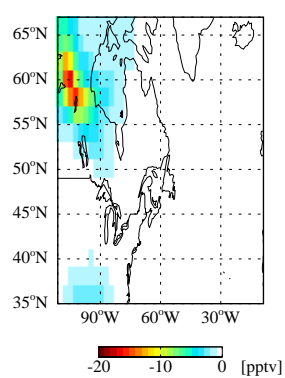

Fig. 12. Model ozone, $\mathrm{CO}, \mathrm{PAN}$, and $\mathrm{NO}_{\mathrm{x}}$ distributions across North America and the North Atlantic at 500 hPa averaged over the BORTASA campaign period, 12 July to 4 August 2010. The top row shows the mean distributions from the model simulation with the scaled FLAMBE inventory derived from the MOPITT CO inversion. The absolute differences compared to the model outputs with the original FLAMBE emissions are shown in the bottom row.

the North Atlantic. The largest differences (less than half the peak values over the fire regions for all tracers) are generally poleward of $50^{\circ} \mathrm{N}$ with smaller differences across the rest of the domain, with the exception of $\mathrm{NO}_{\mathrm{x}}$, which is more localised to the source region with only smaller differences across Maritime Canada. The differences associated with scaling the non-boreal biomass burning emissions (e.g. in the southern and eastern US) are more prominent in the ozone and $\mathrm{CO}$ distributions than for PAN and $\mathrm{NO}_{\mathrm{x}}$. The peak mean PAN and $\mathrm{NO}_{\mathrm{x}}$ mixing ratios are centred over the eastern US and are approximately a factor of 2 for PAN, and 4 for $\mathrm{NO}_{\mathrm{x}}$, higher than their respective distributions over the Canadian biomass burning regions.

To evaluate the impact of scaling the biomass burning emission estimates on the model ozone distribution, we calculate the mean and standard deviation of the differences between the model ozone profiles, from the original and scaled simulations, and the ozonesonde, TES, and IASI observations. Figure 13 shows the mean and standard deviation profiles of the differences, in ppbv, between the model ozone and (a) ozonesondes, (b) TES, and (c) IASI. In all cases model ozone profiles are sampled at the time and location of each observation with black dashed lines showing the original model simulation and red solid lines showing the simulation with the scaled biomass burning emissions. The thicker central lines in each plot show the mean profile with the thinner outer lines showing the mean plus and minus the 1- $\sigma$ standard deviation. In Fig. 13a and $\mathrm{b}$ the reported biases in the retrieved ozone profiles have been taken into account as described in Sects. 4.3.1 and 4.3.2.

The ozonesonde comparison shows a positive bias throughout the troposphere decreasing from $+9 \mathrm{ppbv}$ between $0.5-1 \mathrm{~km}$ to almost $0 \mathrm{ppbv}$ at $6 \mathrm{~km}$. Above $8 \mathrm{~km}$, the bias becomes negative decreasing to $-15 \mathrm{ppbv}$ at $10 \mathrm{~km}$. Scaling the biomass burning emission estimates downwards as described above leads to a better agreement between the mean model and ozonesonde profiles in the lower troposphere, below $5 \mathrm{~km}$, and between 6.5 and $8 \mathrm{~km}$ with a mean bias of almost 0 ppbv. At altitudes between 5 and $6.5 \mathrm{~km}$ the reduction in the ozone profile, where the original bias was $0 \mathrm{ppbv}$, leads to a slight negative bias up to $-2 \mathrm{ppbv}$. The mean difference, averaged from $0-10 \mathrm{~km}$, of the bias is reduced from $2.96 \mathrm{ppbv}$ for the original simulation to $0.88 \mathrm{ppbv}$ for the scaled simulation. The TES comparison shows a negative bias between 2 and $6 \mathrm{~km}$, with values as low as $-2 \mathrm{ppbv}$, and a positive bias above $6 \mathrm{~km}$ which increases to more than $20 \mathrm{ppbv}$ at $10 \mathrm{~km}$. The mean and median of the bias are $1.98 \mathrm{ppbv}$ and $0.04 \mathrm{ppbv}$, respectively, which are reduced to $0.94 \mathrm{ppbv}$ and $-0.73 \mathrm{ppbv}$ with the optimised biomass burning emission estimates. The IASI comparison shows a positive bias throughout the troposphere up to $8-8.5 \mathrm{~km}$, with a peak value of $3.6 \mathrm{ppbv}$, and a negative bias, of $-5 \mathrm{ppbv}$ at $10 \mathrm{~km}$, in the upper troposphere with both a mean and median of the bias of $2.8 \mathrm{ppbv}$, respectively, which are reduced to $1.4 \mathrm{ppbv}$ and $1.1 \mathrm{ppbv}$ with the optimised biomass burning emission estimates. For each comparison the change in the 

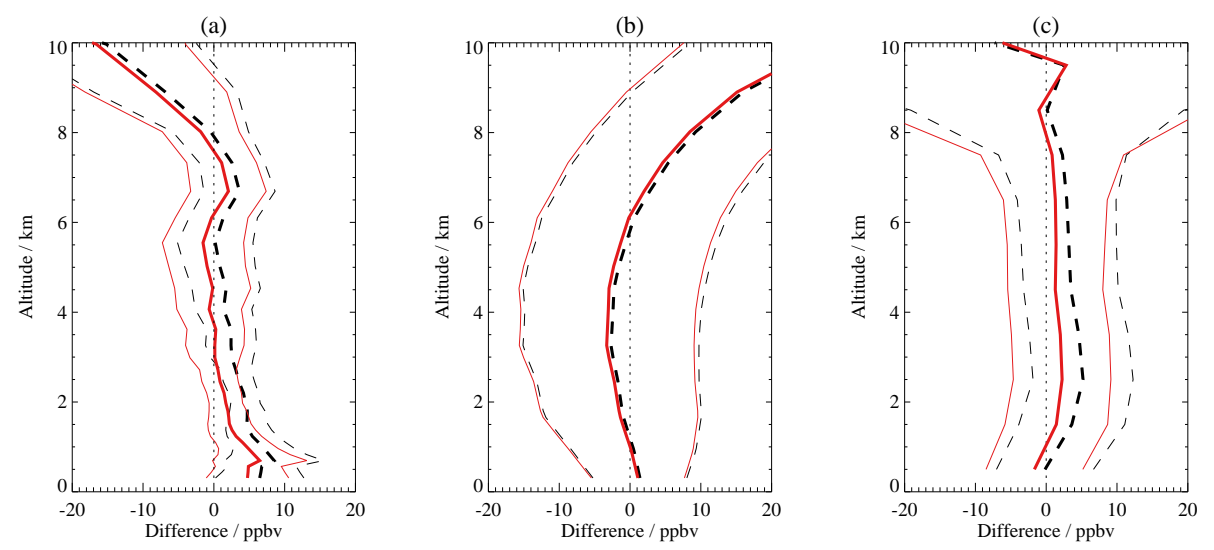

Fig. 13. Mean difference profiles (ppbv) of the model ozone output to (a) ozonesonde, (b) TES, and (c) IASI data averaged over the BORTAS-A campaign period (12 July to 4 August 2010). The model output is sampled at the time and location of the observed profiles for each dataset. Black dashed lines show the mean difference of the model output with the original FLAMBE inventory to the data and red solid lines show the difference of the model output with the scaled FLAMBE emissions derived from the MOPITT CO inversion. The thinner outer lines in each plot show the $1-\sigma$ standard deviations.

mean bias is within the 1- $\sigma$ variability. The mean bias compared to the Pico Mountain Observatory observations, not shown, is also decreased from $5.54 \mathrm{ppbv}$ to $3.95 \mathrm{ppbv}$ averaged over the BORTAS-A campaign period.

\section{Conclusions}

We have presented an evaluation of the tropospheric ozone distribution over North America and the North Atlantic during the summer of 2010 and its sensitivity to boreal biomass burning emissions. We used the GEOS-Chem CTM to calculate the global 3-D tropospheric ozone distribution and compared it against in situ observations from ozonesondes across Canada and the Pico Mountain Observatory in the mid-Atlantic Ocean, and satellite observations from TES and IASI. We showed that the model ozone distribution has a mean bias of less than $10 \mathrm{ppbv}$ throughout the troposphere. We also compared model $\mathrm{CO}$ and $\mathrm{NO}_{\mathrm{x}}$ outputs against observations made at the Pico Mountain Observatory and found that while the model $\mathrm{CO}$ had some agreement with the observations, with a mean bias of $-1.8 \%$, the model $\mathrm{NO}_{\mathrm{x}}$ was biased low by $-44.5 \%$ and did not capture the observed variability. The model underestimate of the variability in the observed $\mathrm{NO}_{\mathrm{x}}$ mixing ratios illustrates that while the model is capable of simulating the distribution of longer lived tropospheric species such as ozone and $\mathrm{CO}$, the distribution of shorter lived species, such as $\mathrm{NO}_{\mathrm{x}}$, is not fully resolved which in turn could account for some of the differences in the model ozone distribution when compared against observations. The discrepancy between the model and observed $\mathrm{NO}_{\mathrm{x}}$ was beyond the scope of this paper and will be addressed in further work under the BORTAS project when evaluating the composition of boreal biomass burning plumes and their im- pact on the tropospheric oxidant chemistry over the North Atlantic.

We used the adjoint of GEOS-Chem to calculate the sensitivity of ozone in the free troposphere over ozonesonde launch sites in the maritime provinces of Canada to biomass burning $\mathrm{NO}_{\mathrm{x}}$ emissions relative to other sources of $\mathrm{NO}_{\mathrm{x}}$ emission in July 2010. Having identified the model ozone sensitivity to biomass burning emissions, the adjoint of GEOS-Chem was further used to optimize the FLAMBE biomass burning inventory used in the GEOS-Chem simulations through an inversion of MOPITT CO profile data using a 4-D variational assimilation framework. The MOPITT CO inversion shows that the FLAMBE inventory overestimates the $\mathrm{CO}$ emissions throughout the Northern Hemisphere and the calculated scaling factors show that in the boreal regions the FLAMBE emissions need to be scaled to as little as $22 \%$ and $20 \%$, or mean scalings of $72 \%$ and $82 \%$, of their original values across Canada and Eastern Siberia, respectively. Scaling ozone precursor emissions from the FLAMBE inventory with the monthly factors calculated by the $\mathrm{CO}$ inversion in a full chemistry forward simulation reduced the model mixing ratios of $\mathrm{CO}$ and $\mathrm{NO}_{\mathrm{x}}$, which are directly emitted by biomass burning, and PAN which, although not directly emitted, is strongly influenced by biomass burning by conversion of $\mathrm{NO}_{\mathrm{x}}$ in the outflow, at $500 \mathrm{hPa}$ by up to approximately $-50 \%$ in the average values calculated over a three week period between 12 July and 4 August 2010.

We showed the impact of the optimized FLAMBE inventory on the model ozone distribution was small relative to the directly emitted tracers, with decreases of up to -3 ppbv or $-8 \%$ averaged over the BORTAS-A campaign period. The change in the model ozone, and its mean difference compared to the ozonesonde, TES, and IASI observations, decreased by approximately $2-3$ ppbv throughout the 
troposphere. The mean bias between the model ozone and ozonesonde profiles was reduced throughout the troposphere between the surface and $8 \mathrm{~km}$ from $2.96 \mathrm{ppbv}$ to $0.88 \mathrm{ppbv}$. We found a similar improvement in the mean tropospheric bias when the model was compared against the satellite observations, taking into account their reported biases, with a reduction from $1.98 \mathrm{ppbv}$ to $0.94 \mathrm{ppbv}$ for TES and $2.8 \mathrm{ppbv}$ to $1.4 \mathrm{ppbv}$ for IASI. In comparison against each dataset, the change in the model bias was within the natural variability of the observations. Although these a posteriori changes in the model ozone are relatively small, when averaged over the BORTAS-A campaign period, larger perturbations should be anticipated over shorter time-scales and in air masses directly associated with biomass burning plumes. Subsequent analyses under the BORTAS project will investigate more specific cases, and will include a more detailed analysis of different chemical species associated with biomass burning in both the model and the observations.

The adjoint sensitivity analysis of the model ozone distribution in the free troposphere showed that $\mathrm{NO}_{\mathrm{x}}$ emission estimates from anthropogenic sources and lightning over North America also have a significant influence. A recent study has shown that the anthropogenic $\mathrm{NO}_{\mathrm{x}}$ emissions over North America decreased by approximately $6 \%$ during 2006-2009 (Lamsal et al., 2011) which is not taken into account in the emissions estimates used by GEOS-Chem. For the lightning emissions, limitations in the model ability to reproduce the distribution of lightning intensities has been shown to underestimate the tropospheric ozone distribution relative to TES observations over North America (Jourdain et al., 2010). Evaluating these uncertainties in the anthropogenic and lightning $\mathrm{NO}_{\mathrm{x}}$ emissions estimates were beyond the scope of the work presented here but further research under the BORTAS project will address these emissions sources and quantify their influence on the model ozone distribution.

The second phase of the BORTAS project (BORTAS-B) was an aircraft measurement campaign with the UK FAAM BAe146 research aircraft, which took place from 12 July to 3 August 2011. Instrumentation on the BAe146 provided a comprehensive suite of measurements of species associated with biomass burning in the outflow to the North Atlantic throughout the free troposphere. In particular, a Laser Induced Fluorescence system (Dari-Salisburgo et al., 2009) measured $\mathrm{NO}_{2}$ and speciated $\mathrm{NO}_{\mathrm{y}}$. Results from these measurements will provide valuable constraints for evaluating the model ozone distribution to its precursors and the chemistry within the biomass burning outflow. Analysis of the BORTAS-B campaign data will build on the results of the BORTAS-A campaign presented here, by utilising a more detailed chemical mechanism derived from the Master Chemical Mechanism (Jenkin et al., 2008) to interpret tropospheric composition over North America and the North Atlantic observed.
Acknowledgements. The BORTAS project is funded by the Natural Environment Research Council under grant NE/F017391/1. DKH is supported through the NASA New Investigator Program. EJH participation was funded by NASA IDS award \#NNH07AF47I. PIP acknowledges funding for EMB from the Nuffield Foundation undergraduate bursary for summer 2010 and from Leverhulme Philip Prize for the summer of 2011. Measurements at the Pico Mountain Observatory were funded by the US National Science Foundation award \#AGS1011968. PFC is Research Associate (Chercheur Qualifié) with F.R.S.-FNRS. The research in Belgium was funded by the F.R.S.-FNRS, the Belgian State Federal Office for Scientific, Technical and Cultural Affairs and the European Space Agency (ESA-Prodex arrangements). Financial support by the 'Actions de Recherche Concertée' (Communauté Française de Belgique) is also acknowledged. IASI has been developed and built under the responsibility of the Centre National des Etudes Spatiales (CNES, France). The IASI L1C data are distributed in near real time by Eumetsat through the Eumetcast dissemination system. The authors acknowledge the Ether French atmospheric database (http://ether.ipsl.jussieu.fr) for providing the IASI data. MOPITT $\mathrm{CO}$ and TES ozone data were obtained from the NASA Langley Research Center Atmospheric Science Data Center.

Edited by: D. Shindell

\section{References}

Alvarado, M. J., Logan, J. A., Mao, J., Apel, E., Riemer, D., Blake, D., Cohen, R. C., Min, K.-E., Perring, A. E., Browne, E. C., Wooldridge, P. J., Diskin, G. S., Sachse, G. W., Fuelberg, H., Sessions, W. R., Harrigan, D. L., Huey, G., Liao, J., CaseHanks, A., Jimenez, J. L., Cubison, M. J., Vay, S. A., Weinheimer, A. J., Knapp, D. J., Montzka, D. D., Flocke, F. M., Pollack, I. B., Wennberg, P. O., Kurten, A., Crounse, J., St. Clair, J. M., Wisthaler, A., Mikoviny, T., Yantosca, R. M., Carouge, C. C., and Le Sager, P.: Nitrogen oxides and PAN in plumes from boreal fires during ARCTAS-B and their impact on ozone: an integrated analysis of aircraft and satellite observations, Atmos. Chem. Phys., 10, 9739-9760, doi:10.5194/acp-10-97392010, 2010.

Andreae, M. O. and Merlet, P.: Emission of trace gases and aerosols from biomass burning, Global Biogeochem. Cy., 15, 955-966, 2001.

Arellano, A. F., Kasibhatla, P. S., Giglio, L., van der Werf, G. R., Randerson, J. T., and Collatz, G. J.: Time-dependent inversion estimates of global biomass-burning $\mathrm{CO}$ emissions using Measurement of Pollution in the Troposphere (MOPITT) measurements, J. Geophys. Res., 111, D09303, doi:10.1029/2005JD006613, 2006.

Beer, R., Glavich, T. A., and Rider, D. M.: Tropospheric emission spectrometer for the Earth Observing System's Aura satellite, Appl. Optics, 40, 2356-2367, 2001.

Bowman, K. W., Rodgers, C. D., Kulawik, S. S., Worden, J., Sarkissan, E., Osterman, G., Steck, T., Lou, T., Eldering, A., Shephard, M., Worden, H. M., Lampel, M., Clough, S., Brown, P., Rinsland, C., Gunson, M., and Beer, R.: Tropospheric emission spectrometer: Retrieval method and error analysis, IEEE Trans. Geosci. Remote Sens., 44, 1297-1307, 2006. 
Bowman, K. W., Jones, D. B. A., Logan, J. A., Worden, H., Boersma, F., Chang, R., Kulawik, S., Osterman, G., Hamer, P., and Worden, J.: The zonal structure of tropical $\mathrm{O}_{3}$ and $\mathrm{CO}$ as observed by the Tropospheric Emission Spectrometer in November 2004 - Part 2: Impact of surface emissions on $\mathrm{O}_{3}$ and its precursors, Atmos. Chem. Phys., 9, 3563-3582, 2009,

http://www.atmos-chem-phys.net/9/3563/2009/.

Boxe, C. S., Worden, J. R., Bowman, K. W., Kulawik, S. S., Neu, J. L., Ford, W. C., Osterman, G. B., Herman, R. L., Eldering, A., Tarasick, D. W., Thompson, A. M., Doughty, D. C., Hoffman, M. R., and Oltmans, S. J.: Validation of northern latitude Tropospheric Emission Spectrometer stare ozone profiles with ARC-IONS sondes during ARCTAS: sensitivity, bias and error analysis, Atmos. Chem. Phys., 10, 9901-9914, doi:10.5194/acp10-9901-2010, 2010.

Boynard, A., Clerbaux, C., Coheur, P.-F., Hurtmans, D., Turquety, S., George, M., Hadji-Lazaro, J., Keim, C., and MeyerArnek, J.: Measurements of total and tropospheric ozone from IASI: comparison with correlative satellite, ground-based and ozonesonde observations, Atmos. Chem. Phys., 9, 6255-6271, doi:10.5194/acp-9-6255-2009, 2009.

Clerbaux, C., Boynard, A., Clarisse, L., George, M., Hadji-Lazaro, J., Herbin, H., Hurtmans, D., Pommier, M., Razavi, A., Turquety, S., Wespes, C., and Coheur, P.-F.: Monitoring of atmospheric composition using the thermal infrared IASI/MetOp sounder, Atmos. Chem. Phys., 9, 6041-6054, doi:10.5194/acp-9-6041-2009, 2009.

Coheur, P.-F., Barret, B., Turquety, S., Hurtmans, D., Hadji-Lazaro, J., and Clerbaux, C.: Retrieval and characterization of ozone vertical profiles from a thermal infrared nadir sounder, J. Geophys. Res., 110, D24303, doi:10.1029/2005JD005845, 2005.

Coheur, P.-F., Clarisse, L., Turquety, S., Hurtmans, D., and Clerbaux, C.: IASI measurements of reactive trace species in biomass burning plumes, Atmos. Chem. Phys., 9, 5655-5667, doi:10.5194/acp-9-5655-2009, 2009.

Dari-Salisburgo, C., Di Carlo, P., Giammaria, F., Kajii, Y., and D'Altorio, A.: Laser induced fluorescence instrument for $\mathrm{NO}_{2}$ measurements: Observations at a central Italy background site, Atmos. Environ., 43, 970-977, 2009.

Deeter, M. N., Edwards, D. P., Gille, J. C., Emmons, L. K., Francis, G., Ho, S.-P., Mao, D., Masters, D., Worden, H., Drummond, J. R., and Novelli, P. C.: The MOPITT version 4 CO product: Algorithm enhancements, validation, and long-term stability, J. Geophys. Res., 115, D07306, doi:10.1029/2009JD013005, 2010.

Derwent, R. G., Stevenson, D. S., Collins, W. J., and Johnson, C. E.: Intercontinental transport and the origins of the ozone observed at surface sites in Europe, Atmos. Environ., 38, 18911901, 2004.

Drummond, J. R., Zou, J., Nichitiu, F., Kar, J., Deschambaut, R., and Hackett, J.: A review of 9-year performance and operation of the MOPITT instrument, Advance Space Res., 45, 760-774, 2010.

Duck, T. J., Firanski, B. J., Millet, D. B., Goldstein, A. H., Allan, J., Holzinger, R., Worsnop, D. R., White, A. B., Stohl, A., Dickinson, C. S., and van Donkelaar, A.: Transport of forest fire emissions from Alaska and the Yukon Territory to Nova Scotia during summer 2004, J. Geophys. Res., 112, D10S44, doi:10.1029/2006JD007716, 2007.

Dufour, G., Eremenko, M., Griesfeller, A., Barret, B., LeFlochmon,
E., Clerbaux, C., Hadji-Lazaro, J., Coheur, P.-F., and Hurtmans, D.: Validation of three different scientific ozone products retrieved from IASI spectra using ozonesondes, Atmos. Meas. Tech. Discuss., 4, 5425-5479, doi:10.5194/amtd-4-5425-2011, 2011.

Duncan, B. N., Logan, J. A., Bey, I., Megretskaia, I. A., Yantosca, R. M., Novelli, P. C., Jones, N. B., and Rinsland, C. P.: Global budget of CO, 1988-1997: Source estimates and validation with a global model, J. Geophys. Res., 112, D22301, doi:10.1029/2007JD008459, 2007.

Fehsenfeld, F. C., Daum, P., Leaitch, W. R., Trainer, M., Parrish, D. D., and Hübler, G.: Transport and processing of $\mathrm{O}_{3}$ and $\mathrm{O}_{3}$ precursors over the North Atlantic: An overview of the 1993 North Atlantic Regional Experiment (NARE) summer intensive, J. Geophys. Res., 101, 28877-28891, 1996.

Fehsenfeld, F. C., Ancellet, G., Bates, T. S., Goldstein, A. H., Hardesty, R. M., Honrath, R., Law, K. S., Lewis, A. C., Leaitch, R., McKeen, S., Meagher, J., Parrish, D. D., Pszenny, A. A. P., Russell, P. B., Schlager, H., Seinfeld, J., Talbot, R., and Zbinden, R.: International Consortium for Atmospheric Research on Transport and Transformation (ICARTT): North America to Europe Overview of the 2004 summer field study, J. Geophys. Res., 111, D23S01, doi:10.1029/2006JD007829, 2006.

Fisher, J. A., Jacob, D. J., Purdy, M. T., Kopacz, M., Le Sager, P., Carouge, C. C., Holmes, C. D., Yantosca, R. M., Batchelor, R. L., Strong, K., Diskin, G. S., Fuelberg, H. E., Holloway, J. S., Hyer, E. J., McMillan, W. W., Warner, J., Streets, D. G., Zhang, Q., Wang, Y., and Wu, S.: Source attribution and interannual variability of Arctic pollution in spring constrained by aircraft (ARCTAS, ARCPAC) and satellite (AIRS) observations of carbon monoxide, Atmos. Chem. Phys., 10, 977-996, doi:10.5194/acp-10-977-2010, 2010.

Flatoy, F., Hov, O., Gerbig, C., and Oltmans, S. J.: Model studies of the meteorology and chemical composition of the troposphere over the North Atlantic during August 18-30, 1993, J. Geophys. Res., 101, 29317-29334, 1996.

Fortems-Cheiney, A., Chevallier, F., Pison, I., Bousquet, P., Carouge, C., Clerbaux, C., Coheur, P.-F., George, M., Hurtmans, D., and Szopa, S.: On the capability of IASI measurements to inform about CO surface emissions, Atmos. Chem. Phys., 9, 87358743, doi:10.5194/acp-9-8735-2009, 2009.

Gonzi, S., Feng, L., and Palmer, P. I.: Seasonal cycle of emissions of CO inferred from MOPITT profiles of CO: Sensitivity to pyroconvection and profile retrieval assumptions, Geophys. Res. Lett., 38, L08813, doi:10.1029/2011GL046789, 2011.

Guenther, A., Karl, T., Harley, P., Wiedinmyer, C., Palmer, P. I., and Geron, C.: Estimates of global terrestrial isoprene emissions using MEGAN (Model of Emissions of Gases and Aerosols from Nature), Atmos. Chem. Phys., 6, 3181-3210, doi:10.5194/acp-63181-2006, 2006.

Helmig, D., Tanner, D. M., Honrath, R. E., Owen, R. C., and Parrish, D. D.: Nonmethane hydrocarbons at Pico Mountain, Azores: 1. Oxidation chemistry in the North Atlantic region, J. Geophys. Res., 113, D20S91, doi:10.1029/2007JD008930, 2008.

Henze, D. K., Hakami, A., and Seinfeld, J. H.: Development of the adjoint of GEOS-Chem, Atmos. Chem. Phys., 7, 2413-2433, doi:10.5194/acp-7-2413-2007, 2007.

Honrath, R. E., Owen, R. C., Val Martin, M., Reid, J. S., Lapina, 
K., Fialho, P., Dziobak, M. P., Kleissl, J., and Westphal, D. L.: Regional and hemispheric impacts of anthropogenic and biomass burning emissions on summertime $\mathrm{CO}$ and $\mathrm{O}_{3}$ in the North Atlantic lower free troposphere, J. Geophys. Res., 109, D24310, doi:10.1029/2004JD005147, 2004.

Hudman, R. C., Jacob, D. J., Turquety, S., Leibensperger, E. M., Murray, L. T., Wu, S., Gilliland, A. B., Avery, M., Bertram, T. H., Brune, W., Cohen, R. C., Dibb, J. E., Flocke, F. M., Fried, A., Holloway, J., Neuman, J. A., Orville, R., Perring, A., Ren, X., Sachse, G. W., Singh, H. B., Swanson, A., and Wooldridge, P. J.: Surface and lightning sources of nitrogen oxides over the United States: Magnitudes, chemical evolution and outflow, J. Geophys. Res., 112, D12S05, doi:10.1029/2006JD007912, 2007.

Jenkin, M. E., Watson, L. A., Utembe, S. R., and Shallcross, D. E.: A Common Representative Intermediates (CRI) mechanism for VOC degradation. Part 1: Gas phase mechanism development, Atmos. Environ., 42, 7185-7195, 2008.

Jiang, Z., Jones, D. B. A., Kopacz, M., Liu, J., Henze, D. K., and Heald, C.: Quantifying the impact of model errors on top-down estimates of carbon monoxide emissions using satellite observations, J. Geophys. Res., 116, D15306, doi:10.1029/2010JD015282, 2011.

Jones, D. B. A., Bowman, K. W., Palmer, P. I., Worden, J. R., Jacob, D. J., Hoffman, R. N., Bey, I., and Yantosca, R. M.: Potential of observations from the Tropospheric Emission Spectrometer to constrain continental sources of carbon monoxide, J. Geophys. Res., 108, 4789, doi:10.1029/2003JD003702, 2003.

Jones, D. B. A., Bowman, K. W., Logan, J. A., Heald, C. L., Liu, J., Luo, M., Worden, J., and Drummond, J.: The zonal structure of tropical $\mathrm{O}_{3}$ and $\mathrm{CO}$ as observed by the Tropospheric Emission Spectrometer in November 2004 - Part 1: Inverse modeling of CO emissions, Atmos. Chem. Phys., 9, 3547-3562, 2009, http://www.atmos-chem-phys.net/9/3547/2009/

Jourdain, L., Worden, H. M., Worden, J. R., Bowman, K. W., Li, Q., Eldering, A., Kulawik, S. S., Osterman, G. B., Boersma, K. F., Fisher, B., Rinsland, C. P., Beer, R., and Gunson, M.: Tropospheric vertical distribution of tropical Atlantic ozone observed by TES during the northern African biomass burning season, Geophys. Res. Lett., 34, L04810, doi:10.1029/2006GL028284, 2007.

Jourdain, L., Kulawik, S. S., Worden, H. M., Pickering, K. E., Worden, J., and Thompson, A. M.: Lightning $\mathrm{NO}_{\mathrm{x}}$ emissions over the USA constrained by TES ozone observations and the GEOS-Chem model, Atmos. Chem. Phys., 10, 107-119, doi:10.5194/acp-10-107-2010, 2010.

Kasibhatla, P., Levy II, H., Klonecki, A., and Chameides, W. L.: Three-dimensional view of the large-scale tropospheric ozone distribution over the North Atlantic Ocean during summer, J. Geophys. Res., 101, 29305-29316, 1996.

Kopacz, M., Jacob, D. J., Henze, D. K., Heald, C. L., Streets, D. G., and Zhang, Q.: Comparison of adjoint and analytical Bayesian inversion methods for constraining Asian sources of carbon monoxide using satellite (MOPITT) measurements of CO columns, J. Geophys. Res., 114, D04305, doi:10.1029/2007JD009264, 2009.

Kopacz, M., Jacob, D. J., Fisher, J. A., Logan, J. A., Zhang, L., Megretskaia, I. A., Yantosca, R. M., Singh, K., Henze, D. K., Burrows, J. P., Buchwitz, M., Khlystova, I., McMillan, W. W., Gille, J. C., Edwards, D. P., Eldering, A., Thouret, V., and
Nedelec, P.: Global estimates of $\mathrm{CO}$ sources with high resolution by adjoint inversion of multiple satellite datasets (MOPITT, AIRS, SCIAMACHY, TES), Atmos. Chem. Phys., 10, 855-876, doi:10.5194/acp-10-855-2010, 2010.

Kuhns, H., Knipping, E. M., and Vukovich, J. M.: Development of a United States-Mexico emissions inventory for the Big Bend Regional Aerosol and Visibility Observational (BRAVO) study, J. Air Waste Manage. Assoc., 55, 677-692, 2005.

Lamsal, L., Martin, R. V., Padmanabhan, A., van Donkelaar, A., Zhang, Q., Sioris, C. E., Chance, K., Kurosu, T. P., and Newchurch, M. J.: Application of satellite observations for timely updates to global anthropogenic $\mathrm{NO}_{\mathrm{x}}$ emission inventories, Geophys. Res. Lett., 38, L05810, doi:10.1029/2010GL046476, 2011

Lapina, K., Honrath, R. E., Owen, R. C., Val Martin, M., and Pfister, G.: Evidence of significant large-scale impacts of boreal fires on ozone levels in the midlatitude Northern Hemisphere free troposphere, Geophys. Res. Lett., 33, L10815, doi:10.1029/2006GL025878, 2006.

Lewis, A. C., Evans, M. J., Methven, J., Watson, N., Lee, J. D., Hopkins, J. R., Purvis, R. M., Arnold, S. R., McQuaid, J. B., Whalley, L. K., Pilling, M. J., Heard, D. E., Monks, P. S., Parker, A. E., Reeves, C. E., Oram, D. E., Mills, G., Bandy, B. J., Stewart, D., Coe, H., Williams, P., and Crosier, J.: Chemical composition observed over the mid-Atlantic and the detection of pollution signatures far from source regions, J. Geophys. Res., 112 D10S39, doi:10.1029/2006JD007584, 2007.

Li, Q., Jacob, D. J., Bey, I., Palmer, P. I., Duncan, B. N., Field, B. D., Martin, R. V., Fiore, A. M., Yantosca, R. M., Parrish, D. D., Simmonds, P. G., and Oltmans, S. J.: Transatlantic transport of pollution and its effects on surface ozone in Europe and North America, J. Geophys. Res., 107, 4166, 4166 , doi:10.1029/2001JD001422, 2002

Mauzerall, D. L., Jacob, D. J., Fan, S.-M., Bradshaw, J. D., Gregory, G. L., Sachse, G. W., and Blake, D. R.: Origin of tropospheric ozone at remote high northern latitudes in summer, J. Geophys. Res., 101, 4175-4188, 1996.

McLinden, C. A., Olsen, S. C., Hannegan, B., Wild, O., and Prather, M. J.: Stratospheric ozone in 3-D models: A simple chemistry and the cross-tropopause flux, J. Geophys. Res., 105, 1465314665,2000

Nassar, R., Logan, J. A., Worden, H. M., Megretskaia, I. A., Bowman, K. W., Osterman, G. B., Thompson, A. M., Tarasick, D. W. et al.: Validation of Tropospheric Emission Spectrometer (TES) nadir ozone profiles using ozonesonde measurements, J. Geophys. Res., 113, D15S17, doi:10.1029/2007JD008819, 2008.

Oltmans, S. J., Levy II, H., Harris, J. M., Merrill, J. T., Moody, J. L., Lathrop, J. A., Cuevas, E., Trainer, M., O’Neill, M. S., Prospero, J. M., Vömel, H., and Johnson, B. J.: Summer and spring ozone profiles over the North Atlantic from ozonesonde measurements, J. Geophys. Res., 101, 29179-29200, 1996.

Owen, R. C., Cooper, O. R., Stohl, A., and Honrath, R. E.: An analysis of the mechanisms of North American pollutant transport to the central North Atlantic lower free troposphere, J. Geophys. Res., 111, D23S58, doi:10.1029/2006JD007062, 2006.

Parrington, M., Jones, D. B. A., Bowman, K. W., Horowitz, L. W., Thompson, A. M., Tarasick, D. W., and Witte, J. C.: Estimating the summertime tropospheric ozone distribution over North America through assimilation of observations from the Tropo- 
spheric Emission Spectrometer, J. Geophys. Res., 113, D18307, doi:10.1029/2007JD009341, 2008.

Pickering, K. E., Wang, Y., Tao, W., Price, C., and Müller, J.-F.: Vertical distributions of lightning $\mathrm{NO}_{\mathrm{x}}$ for use in regional and global chemical transport models, J. Geophys. Res., 103, 3120331216, 1998.

Price, C. and Rind, D.: A simple lightning parameterization for calculating global lightning distributions, J. Geophys. Res., 97, 9919-9933, 1992.

Real, E., Law, K. S., Weinzierl, B., Fiebig, M., Petzold, A., Wild, O., Methven, J., Arnold, S., Stohl, A., Huntrieser, H., Roiger, A., Schlager, H., Stewart, D., Avery, M., Sachse, G., Browell, E., Ferrare, R., and Blake, D.: Processes influencing ozone levels in Alaskan forest fire plumes during long-range transport over the North Atlantic, J. Geophys. Res., 112, D10S41, doi:10.1029/2006JD007576, 2007.

Reid, J. S., Prins, E. M., Westphal, D. L., Schmidt, C. C., Richardson, K. A., Christensen, J. H., Eck, T. F., Reid, E. A., Curtis, C. A., and Hoffman, J. P.: Real-time monitoring of South American smoke particle emissions and transport using a coupled remote sensing/box-model approach, Geophys. Res. Lett., 31, L06107, doi:10.1029/2003GL018845, 2004.

Reid, J. S., Hyer, E. J., Prins, E. M., Westphal, D. L., Zhang, J., Wang, J., Christopher, S. A., Curtis, C. A., Schmidt, C. C., Eleuterio, D. P., Richardson, K. A., and Hoffman, J. P.: Global monitoring and forecasting of biomass-burning smoke: Description of and lessons from the Fire Locating And Modeling of Burning Emissions (FLAMBE) program, IEEE J. Select. Topics Appl. Earth Obs. Remote Sens., 2, 144-162, 2009.

Rodgers, C. D.: Inverse Methods for Atmospheric Sounding: Theory and Practice, World Scientific, 2000.

Sauvage, B., Martin, R. V., van Donkelaar, A., Liu, X., Chance, K., Jaeglé, L., Palmer, P. I., Wu, S., and Fu, T.-M.: Remote sensed and in situ constraints on processes affecting tropical tropospheric ozone, Atmos. Chem. Phys., 7, 815-838, doi:10.5194/acp-7-815-2007, 2007.

Tereszchuk, K. A., González Abad, G., Clerbaux, C., Hurtmans, D., Coheur, P.-F., and Bernath, P. F.: ACE-FTS measurements of trace species in the characterization of biomass burning plumes, Atmos. Chem. Phys., 11, 12169-12179, doi:10.5194/acp-1112169-2011, 2011.
TES Science Team: TES L2 Data User's Guide, Tech. rep., Jet Propulsion Laboratory, California Institute of Technology, http: //tes.jpl.nasa.gov/uploadedfiles/TESDataUsersGuideV4_0.pdf, 2009.

Thompson, A. M., Oltmans, S. J., Tarasick, D. W., von der Gathen, P., Smit, H. G. J., and Witte, J. C.: Strategic ozone sounding networks: Review of design and accomplishments, Atmos. Environ., 45, 2145-2163, 2011.

Val Martin, M., Honrath, R. E., Owen, R. C., Pfister, G., Fialho, P., and Barata, F.: Significant enhancements of nitrogen oxides, black carbon, and ozone in the North Atlantic lower free troposphere resulting from North American boreal wildfires, J. Geophys. Res., 111, D23S60, doi:10.1029/2006JD007530, 2006.

Verma, S., Worden, J., Pierce, B., Jones, D. B. A., Al-Saadi, J., Boersma, F., Bowman, K., Eldering, A., Fisher, B., Jourdain, L., Kulawik, S., and Worden, H.: Ozone production in boreal fire smoke plumes using observations from the Tropospheric Emission Spectrometer and the Ozone Monitoring Instrument, J. Geophys. Res., 114, D02303, doi:10.1029/2008JD010108, 2009.

Wang, Y., Jacob, D. J., and Logan, J. A.: Global simulation of troposphereic $\mathrm{O}_{3}-\mathrm{NO}_{\mathrm{x}}$-hydrocarbon chemistry: 1. Model formulation, J. Geophys. Res., 103, 10713-10725, 1998.

Winkler, P.: Surface ozone over the Atlantic Ocean, J. Atmos. Chem., 7, 73-91, 1988.

Zhang, L., Jacob, D. J., Kopacz, M., Henze, D. K., Singh, K., and Jaffe, D. A.: Intercontinental source attribution of ozone pollution at western U.S. sites using an adjoint method, Geophys. Res. Lett., 36, L11810, doi:10.1029/2009GL037950, 2009a.

Zhang, L., Jacob, D. J., Liu, X., Logan, J. A., Chance, K., Eldering, A., and Bojkov, B. R.: Intercomparison methods for satellite measurements of atmospheric composition: application to tropospheric ozone from TES and OMI, Atmos. Chem. Phys., 10, 4725-4739, doi:10.5194/acp-10-4725-2010, 2010.

Zhang, Q., Streets, D. G., Carmichael, G. R., He, K. B., Huo, H., Kannari, A., Klimont, Z., Park, I. S., Reddy, S., Fu, J. S., Chen, D., Duan, L., Lei, Y., Wang, L. T., and Yao, Z. L.: Asian emissions in 2006 for the NASA INTEX-B mission, Atmos. Chem. Phys., 9, 5131-5153, doi:10.5194/acp-9-5131-2009, $2009 \mathrm{~b}$. 